\title{
Indian Monsoons Roaming in Time and Space and Global Climate Calamities Control Vitalities
}

\author{
Malik Muhammad Nazeer \\ Islamabad, Pakistan \\ Email: Naz188nbsg@gmail.com
}

How to cite this paper: Nazeer, M.M. (2020) Indian Monsoons Roaming in Time and Space and Global Climate Calamities Control Vitalities. Open Access Library Journal, 7: e6568

https://doi.org/10.4236/oalib.1106568

Received: July 1, 2020

Accepted: October 12, 2020

Published: October 15, 2020

Copyright () 2020 by author(s) and Open Access Library Inc.

This work is licensed under the Creative Commons Attribution International License (CC BY 4.0).

http://creativecommons.org/licenses/by/4.0/ (c) (i) Open Access

\begin{abstract}
The huge rise in worldwide almost all calamities is the aftermath of extreme Global Heat and Temperature (GHT). These have taken a steep upward turn with continuously flourishing growth since 1965/70, steered by implementation of Indus Basin Water Treaty of 1960 (IBWT). This 16.48 ZJ (Zeta Joules $=10^{21}$ Joules) rate of rising Global Heat could have been reduced by about 9.235 ZJ through optimal development and use of Pakistani resources in its local water evaporation and precipitation cycle (WEPC) of unique characteristics by about 1980, but this only opportunity was missed due to having no vision of forthcoming Global Emergency and its only solution. This and another $15.78 \mathrm{ZJ}$ again with another unique global characteristics are badly needed as soon as possible to block any further continuous growth of GHT and fizzle out its so far accumulated and constantly further expending heap. Almost all of these resources are being wasted as a result of misguidance through wrong and un-logical recommendations based on redundant informations, misconceptions and wrong interpretations. In this work recent reliable data is analyzed and a few basic ideologies are presented to put the things back on the right track in order to handle the Global Environmental Emergencies along with earliest and maximum possible blockage of Global Calamities. The extremities of roaming of Indian monsoon both in time and space are analyzed and what it dictates in design and optimum development of the above referred resources, for both local requirements and most critical needs of Global Emergencies are elaborated.
\end{abstract}

\section{Subject Areas}

Environmental Sciences, Climatology

\section{Keywords}

Freon of Global Air Conditioner, Indian Air Wheels and Monsoons, 
Indus Basin Water Treaty, Irrigation System of Pakistan,

Global Heat Transmission to Troposphere, Major Promoter of Global Calamities,

3 Unique Parts of Pakistani Water Evaporation and Precipitation Cycle,

Global Climates Emergencies

\section{Introduction}

The huge rise in worldwide calamities and highly disastrous Global hazards is the aftermath of extreme Global Heat and Temperature (GHT) [1]. This GHT with its persistent growth rate of $16.48 \mathrm{ZJ}$ (Zeta Joules $=10^{21}$ Joules) per year in place of less than 2 ZJ before 1960 [1] and its generated calamities have taken a very steep upward turn since 1965/70, steered by implementation of Indus Basin Water Treaty (IBWT) of 1960 [1] [2] [3] [4]. Here the share of IBWT contribution is the blockage of $14.235 \mathrm{ZJ}$ Global Heat transport to troposphere through blocking the Freon of Global Air Conditioner (GAC) [1]. This Freon is the 39 MAF water of 3 rivers, irrigating Eastern and Southern Pakistan which was diverted to India under IBWT sponsored by World Bank (WB) and a few major countries [1] [5] [6]. This rolled down the whole Earth Globe to the hell of continuously increasing Calamities and disasters and huge damages to the environmental ecosystem [7]. This 16.48 ZJ dosage to Earth Globe could have been reduced by about $9.893 \mathrm{ZJ}$ through the optimal development and use of remaining water resources of Pakistan by 1980 and $15.78 \mathrm{ZJ}$ further more by further development of new irrigation area in Chulistan, Thar and Thal [1], but having no vision of this Global Climate Emergency (GCE) and no knowledge of its particular major route cause and also with wrong perception of the data, illogical assumptions and irrelevant interpretations, the consultant, the WB [5] [6] not only deferred these opportunities to let the World in general and Pakistan in particular face continuous disasters and huge financial losses, but also rolled many extremely huge hurdles en-route of their future development even at some later stages. In view of the present Global Environment Emergency, the present extreme Global Heat, Temperature [1] and resulting Catastrophic Climatic Calamities, optimal, continuous and uninterrupted operation of GAC is extremely vital not only for the mankind, but also for all living creation on this Globe. This in turn needs continuous, uninterrupted and optimal feed of its Freon, the irrigation water supply only in Pakistan from Indus River System fed by Indian monsoons. The mankind has to scientifically/tactfully manage it from the highly variable flows of its various rivers both mutually and with time as a result of monsoons' roaming both in time and space, directed and dictated by the Nature through cyclic roles of Solar, Lunar and Venus Troika [8] along with human misshapes and drastic inputs generally gone unnoticed. It is therefore, highly inevitable to know the status and pattern of Pakistani rivers flows under roaming of its feeder, the Indian Monsoons. The Monsoons carry on roaming in a year 
from June to November, but generally these are concentrating more from July to August and much rarely in June, October or November. The space roaming dictates the importance of large storage size dams as the entire monsoon load is mostly unloaded in the catchment area of one or two river groups and much rarely in all. In 20 years recorded [9] span (Figure 1(a)), only 3 years (2008, $2010,2016)$ have almost comparable large flow in majority of the rivers [9]. The probability of flow occurrence above the normal in this recorded period is $12 \%$ $14 \%, 18 \%-20 \%, 33 \%-35 \%, 24 \%-26 \%$ and $10 \%-12 \%$ for $4,3,2,1$ and all rivers below normal respectively as discussed below. The $24 \%$ probability of flow above normal for one river only is much critical and it dictates the largest possible storage to be developed for flow of all the 4 rivers. The time roaming has two aspects; roaming within a monsoon season in a year and roaming over many years with variation of rainfall intensity. The first one is not much complex, as the maximum or peak flow is mostly in July and storage handling system must be capable to grasp it's all flow in a weak or two. The last one is acutely most critical and dictates the maximum possible storage of multiple consecutive largest flow years for each river group to grip all the available water and use it suitably distributed based upon multi-year's time domain requirements. Thus, the storage dams on these rivers groups must be fully able to store in all possible adverse conditions and suitably regulate as per all possible needs of global heat dissipation, irrigation and power productions, in all the months of a year and over multiple years in a decade or two as discussed below. This roaming has been elaborated in [8] too for monsoons under lunar multiple cycles of periods $8.85,18.6,37$ and 86 years and also cycles of 3, 4, 5 and 8 years periods forced by the Venus. Water Storage of River Indus flow [9] in years 1998-2002, 2005, 2008 (Figure 1(a)) was needed for usage in years 2003, 2004, 2006, 2007, 2009-2014, that is 7 years with first 5 years continuous storage for regulated use in 10 years over the 17 years time span. Similarly 2004-06 years storage of River Chenab was needed for regulated flow supply in 2007-9 and also 2011-2014 storage needed for regulated flow supply in 2015-17; that is 3 - 4 years continuous storage for regulated use in next 3 years over the two spans of 6 and 7 years. The same decadal years based strategy is needed for Ravi and Sutlej (not recorded), while Kabul flow is smooth on decadal bases and its storage may only be for season based regulation, whereas Jhelum still needs further storage based on decadal regulation. Figure 1(b) shows the various levels and categories of floods flows of 5 rivers along with their mean as well as low/thresholds flows. This indicates the size of seasonal storage quantity on each river.

Another physical confirmation of this may be seen in Indus River System by the variation of floods water flow. The dark blue bars (Figure 2(a)) show the portion of flood water drained to Arabian Sea from Kotri barrage [10] [11] [12], showing strong linkage to 18.6 and 37 years lunar procession dictated cyclic trend [8]. Here total water wasted drained to Arabian Sea is 1164 MAF in 34 years with no instant of any one year at all of no drainage to Arabian Sea. There are only 4 years with drainage below 4 MAF per years and more than $88 \%$ are 
(a) Maximum Flow Discharge

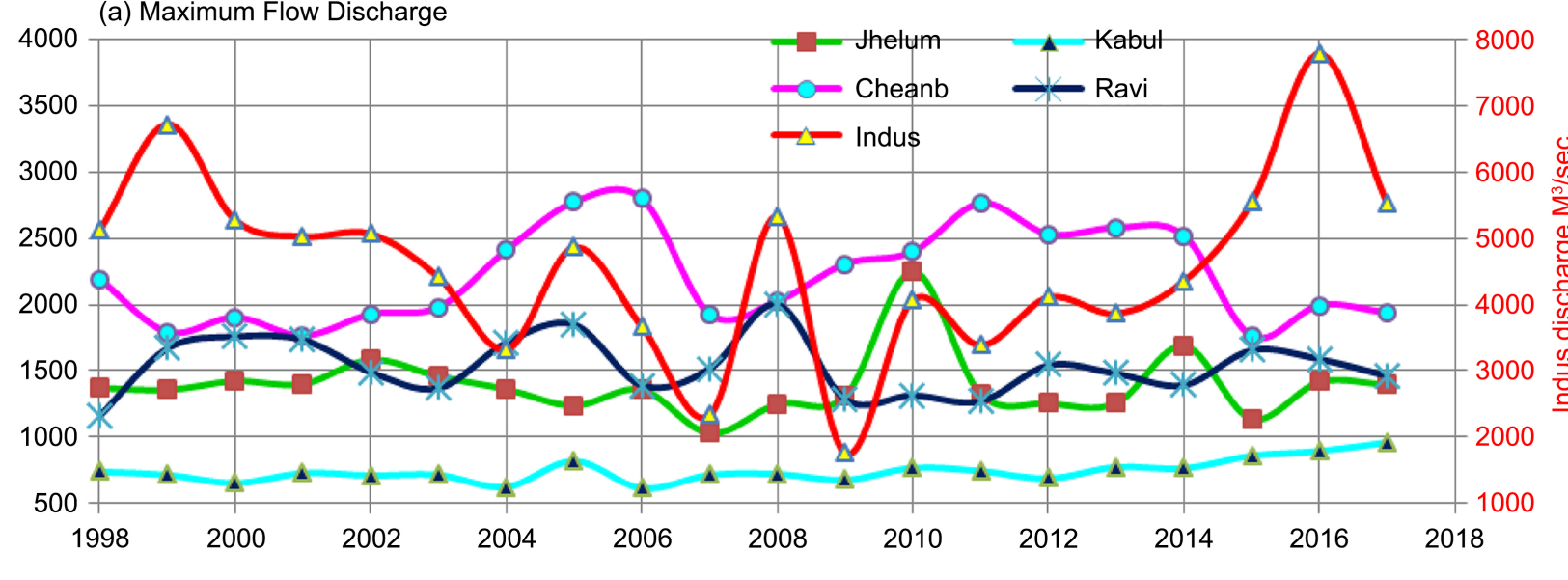

(b) Indus River System Flood Flow Analysis, 1998-2017

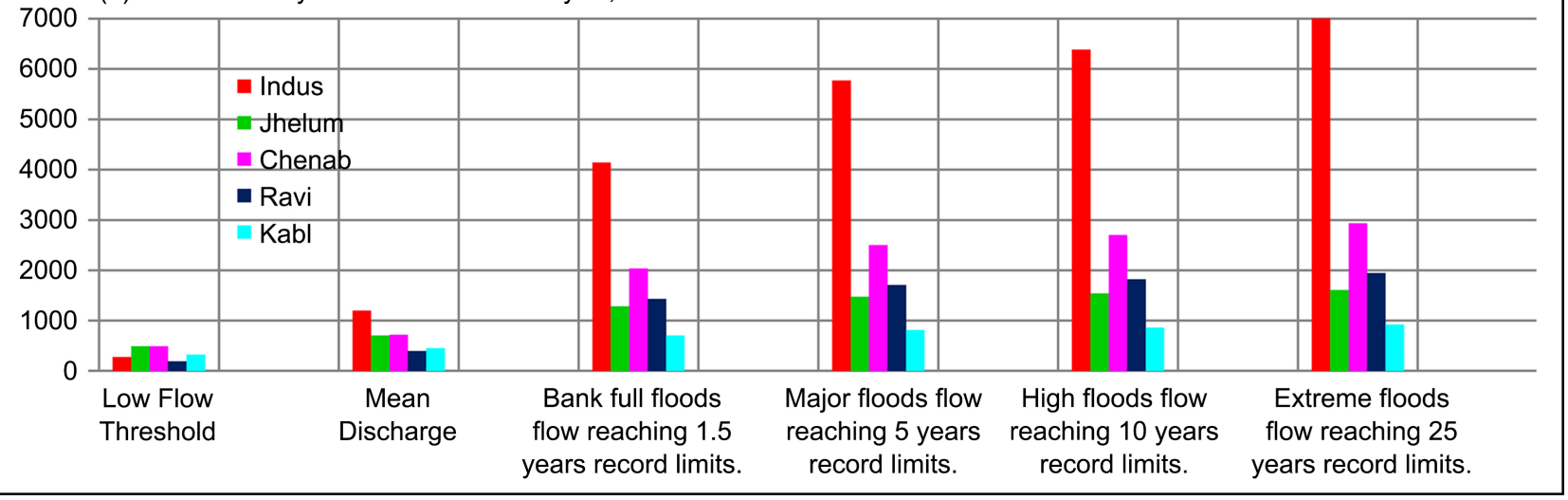

Figure 1. (a) Top graph shows maximum flow discharge in cubic meters/sec of 5 main rivers excluding Sutlej. Indus flow scale is on the right (200\% of others). Kabul flow is somewhat stable while wide fluctuations in all others, particularly the Indus, Chenab and Ravi need large storage for flow regulations in over the year's time roaming scenario of monsoons, evident from their variation; (b) The lower bar chart confirms the above and also shows comparison of their mutual flows and their flow variations among floods categories and with respect to their low flow threshold and mean discharge.

the instances of extreme damages of crops and infrastructures along with huge financial losses and wastage of globally and locally most precious water resource. Straightaway it indicates (see floods of 1973, 76, 78, 92, 94 and 95) that at least 100 MAF storage over and above Mangla and Tarbela dams is the urgent need to avoid the extreme floods damages. Here, a very crucial part of flood water damaging the infrastructures, crops and livestock is ignored altogether in all discussions and references. The red bars (Figure 2(a)) show this part absorbed and also retained standing in flooded area equivalent to flood water exceeding the 30 MAF rivers safe flow capacity (assumed) or river bank full flow to Arabian Sea. This exceeding quantity is also drained to sea with an equivalent part (rather more than that) rushing to flooded areas, which is partly absorbed and partly withheld from draining to sea. Thus sum of the red and blue is the flow worth annual additional storage shown green along with its green trend line. This shows additional 167.4 MAF peak flow storage requirement in place of 100 MAF stated above elaborated by wastage of 1588 MAF in 34 years. 

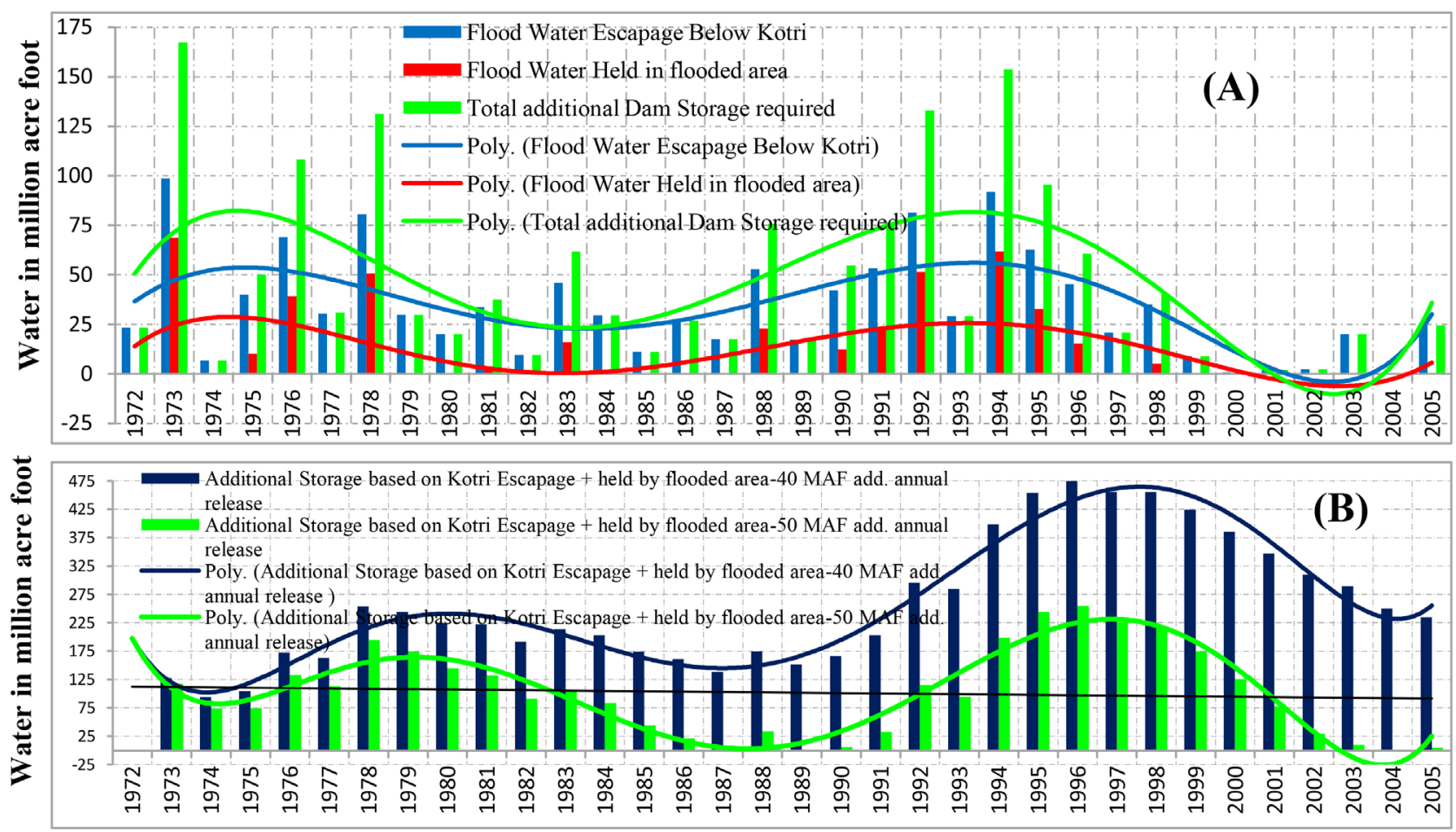

Figure 2. (A) The above is the year vise flow escaped to Arabian Sea (dark blue) from Kotri barrage at the tail [10] [11] [12] with Polynomial trend line (dark blue) showing its flow trend. This shows an additional storage requirement of 100 MAF. Its trend is due to lunar directed period of 18.6 years with higher flows, while the next (truncated) is of lowest flows, thus actually this cycle on earth is of 37 years. At least $2 / 3$ of the 2 nd half cycle will be in critical zone, hence over the years or multi-decade storage and flow regulation minimum requirement is for $18.6+18.6 * 2 / 3=31$ years or $18.6+9.3+2(4$ critical years at center $)=30$ years. The red bars show the flood water absorbed and also retained standing in flooded area assumed to be equivalent to the flood water exceeding about 30 MAF rivers safe flow capacity or river bank full flow to Arabian Sea. Thus sum of the red and blue is the flow worth annual additional storage shown green along with its green trend line, indicating 167.4 MAF additional storage. (B) Shows decadal additional storage and flow regulation strategies, with flow release in multiple of $10 \mathrm{MAF}$ (maximum $50 \mathrm{MAF} / \mathrm{year}$ in one and 40 in second case) when available quantity is more than release. From these two, 40 MAF addition release per year with 475 MAF additional storage seems better to take care of draughts in the dry half cycle of 18.6 years.

In view of 37 years cyclic flow fluctuations [8], storage and release regulation management, additional multiyear storage is shown (Figure 2(b)) in blue and green bars with the release of additional flow to irrigation in multiple of $10 \mathrm{MAF}$ (max. blue-40 and green-50 MAF) per year if the preceding storage is sufficiently more than that. This shows an additional storage of green-255 MAF and blue-475 MAF in place of 167 . The $475 \mathrm{MAF}$ (+ 21.5 existing = 497 MAF) storage seems to be much better facilitating the promising irrigation supply in draughts in the dry half cycle of 18.6 years. Unknowingly, the World Bank (WB) through sponsoring the Indus Basin Water Treaty (IBWT) 1960 [1] [2] [3] [4] blocked the Freon (the water irrigating southeastern Pakistan) supply to the Giant GAC since 1965-70 and thus has put the Earth Globe on silent colorless fire. Not confined and limited to this, but by its recommendations recorded in [13] has also derailed and misled the remaining potential of Pakistan which could extinguish at least 70\% (9.893 ZJ) of this fire. This continuous dosage of 
heat to earth Globe is also attacking furiously on its two main temperature relievers or safety valves, the Oceans and polar' and glaciers' ice heaps/dunes and these both are monotonically giving way to this attack almost exactly matching in time and intensity of attacks [1]. If properly assessed, daily global death toll almost 60,000 out of about 180,000 since 1970 may be connected by one way or the other to the aftermath of this Silent Unspotted Crona-1960 (SUC-60), the IBWT-1960. Both the first two issues have been in wide discussion in the scientific community without hitting at its main cause, the IBWT and hence without any fruitful Solution. Alas, the Organization for Global Developments and $\mathrm{Hu}$ man Welfare silently hurled everlasting wildfire of all the continuous Calamities and Climatic Disasters on the Earth Globe through IBWT [5] [6] on one hand and blocked its potential reliever/firefighters, the Pakistan's local water cycle through its recommendations [13] on the other hand. The aftermath and mechanism of its first misdeed has been elaborated in the references [1] [2] [3] [4], while the $2^{\text {nd }}$ with its report in 3 volumes of about 400 pages each needs separate work for analysis of the subjects having critical role in blocking the relief operation in Global Environments and Heating Extremities, however, its few paradigm and assessments parameters are reviewed in the light of outcome of recent data [9] analysis. Over and above the large share borne by Pakistan of these global calamities, it has also further particularly been ruined by floods disasters, huge losses from deprival of huge agricultural, industrial output and huge 30 35 times extra financial load through costly electrical power advised to generate from imported costly petroleum in place of cheapest hydropower from the extremely demanded multipurpose dams. World Bank (WB) has made number of absolutely baseless, unscientific and illogical assumptions [13], all against the demands of control strategy of Global Heat and Temperature rise, Global Climate lashes and Calamities over and above being absolutely against the safety of Pakistan from floods disaster and its stringent requirements to benefit from its water resources both in irrigation and power generation. Thus its recommendations have blocked the huge possible role of Pakistan in Global Heat dissipation along with debarring its developments and safety from floods and drought disasters. Before the review and analysis of those assumption and paradigm in view of the present Global Climatic Emergency in the scenario of unique and extremely crucial role of Pakistani water cycle based on Indus River System flow, it is found prerequisite to analyze the flow pattern of this system under roaming of its feeder, the monsoons both in time and space. The Indus Rivers System flow in winter is too small for any considerations, while in summer, it is in form of huge floods, which if properly stored for flood disaster control, irrigation and power generation can meet all the local and Global Environmental requirements and thus need highest and critical considerations and attentions. Fortunately the data of recent 21 years flood flow of five rivers is available in [9], while flood flow of River Sutlej is not recoded, although it is perishing Pakistan mercilessly every $2^{\text {nd }}$ or $3^{\text {rd }}$ year with the willful support of India. The flow of Kabul River 
over the decades is smooth enough and hence only annual flow regulation is needed, while the decadal flow pattern of all the rest of four rivers (+Sutlej) needs deep consideration for decadal or multiyear flow storage and regulation. The flow fluctuations of these 4 rivers are analyzed here below.

\section{Indus River System Flows Pattern and Seasonal Monsoons Roaming}

The monthly time versus flow of 4 rivers has three patterns. Ravi, Chenab and the Sutlej rivers have similar average flow pattern per month, while Jhelum and Indus have their own patterns (Figure 3) as discussed bellow in detail.

\subsection{Ravi and Sutlej Rivers Flood Flows}

With the IBWT diversion of Ravi and Sutlej rivers to India by 1970, their flow other than in monsoons months is absolutely negligible, just by rains downstream of the diversion or by the feeder canals within Pakistan. The flow pattern

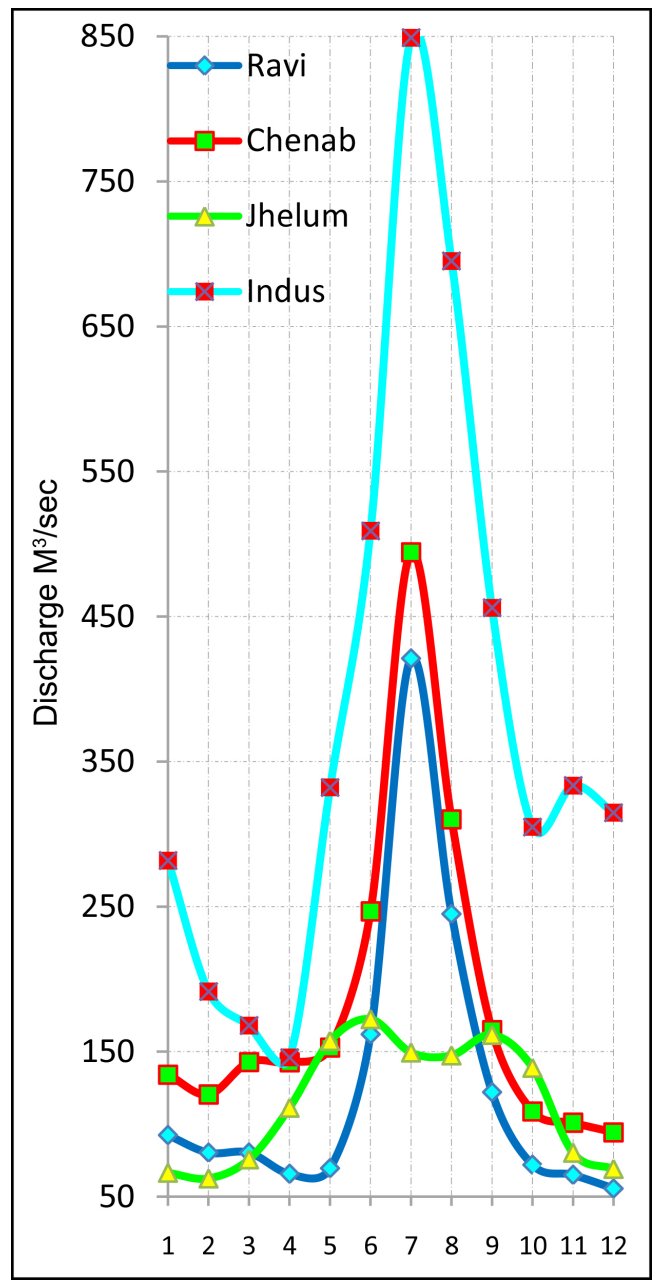

Figure 3. Average month vise flow trends of Indus River System. Ravi and Chenab have similar, while Jhelum and Indus have different trends. 
of both rivers is almost same. Flow of Sutlej is not recorded in [9], hence only Ravi flows (Figure 4) are analyzed and Sutlej is assumed at par with it. In the monsoons with the heavy rains fall, flow in form of large floods boosted by the Indians tactics is experienced every year. As per Figure 4, both yearly and monthly running pattern, its flow is maximum in July every year, while much lower in August, June, September and October in all the 21 years, whereas its extraordinary flows (Figure 4) in 2000, 2005, 2008 and 2018 (19\%) indicate decadal monsoon roaming. On monthly bases, there is no roaming, confined only to July and that too for 5 - 15 days. Their average flow level values per respective peak month are 158.1, 90.25, 59.8, 45 and $27 \mathrm{~mm}$ respectively, and their peak values are $207.4,121.8,88.4,58.3,37.6 \mathrm{~mm}$ over the 21 years span. The data presented in [9] record is integrated sum over whole the month, while actually this all flood flow is generally for 5 - 15 days with peak within $4-5$ days. There is no entry of any month other than July having all 21 in extreme flow zone except August in year 2005 recorded in table in Figure 10 also.

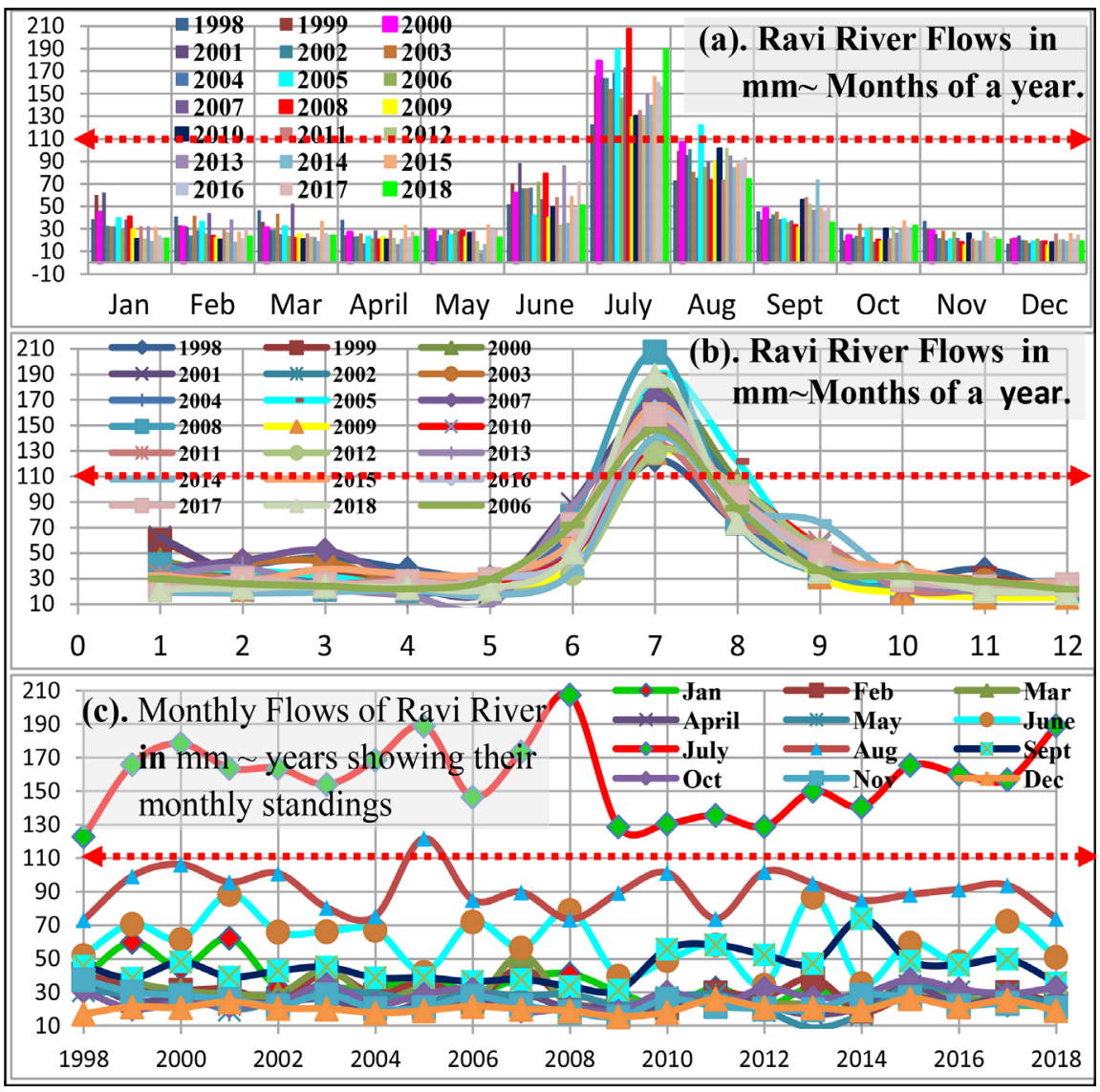

Figure 4. The (a) and (b) graphs show yearly month vise trend of Ravi river flow, while the (c) graph shows the same flow versus years and this clearly show its monthly standing in 21 years span. Its flow is extreme in July every year, while only once August 2005 crossed $110 \mathrm{~mm}$ barrier. Almost, similar behavior is that of River Sutlej. In the rest of the months, flow is about $25 \mathrm{~mm}$. The peak flood flows are for a week or so, but these are shown moderated with summation over a month. 


\subsection{Chenab River Flood Flow}

With the control of flow of this river too by India through construction of multiple dams in the name of power generation, its flow (Figure 5(a), Figure 5(b)) in July is maximum in every year. There is almost no seasonal roaming, rather confined only to July. The May to October average flow level values are as 28.63, $46.35,93.74,58.51,30.86$ and $20.64 \mathrm{~mm}$ respectively, and their peak values are as $46.4,66.6,112.3,81.8,71.9$ and $33.7 \mathrm{~mm}$ over the 21 years recorded span. Again the data presented in [9] record is integrated sum of the whole month, while actually this all flood flow is generally for a 7 - 10 days with peak flow only in 4 - 5 days at any point along its channel. The total monthly peak flow status (Figure 5(c)) in these 21 years is as, June has 1, July 21, August 8 and September has 1 entry in peak flow zone as shown in the table in Figure 10.

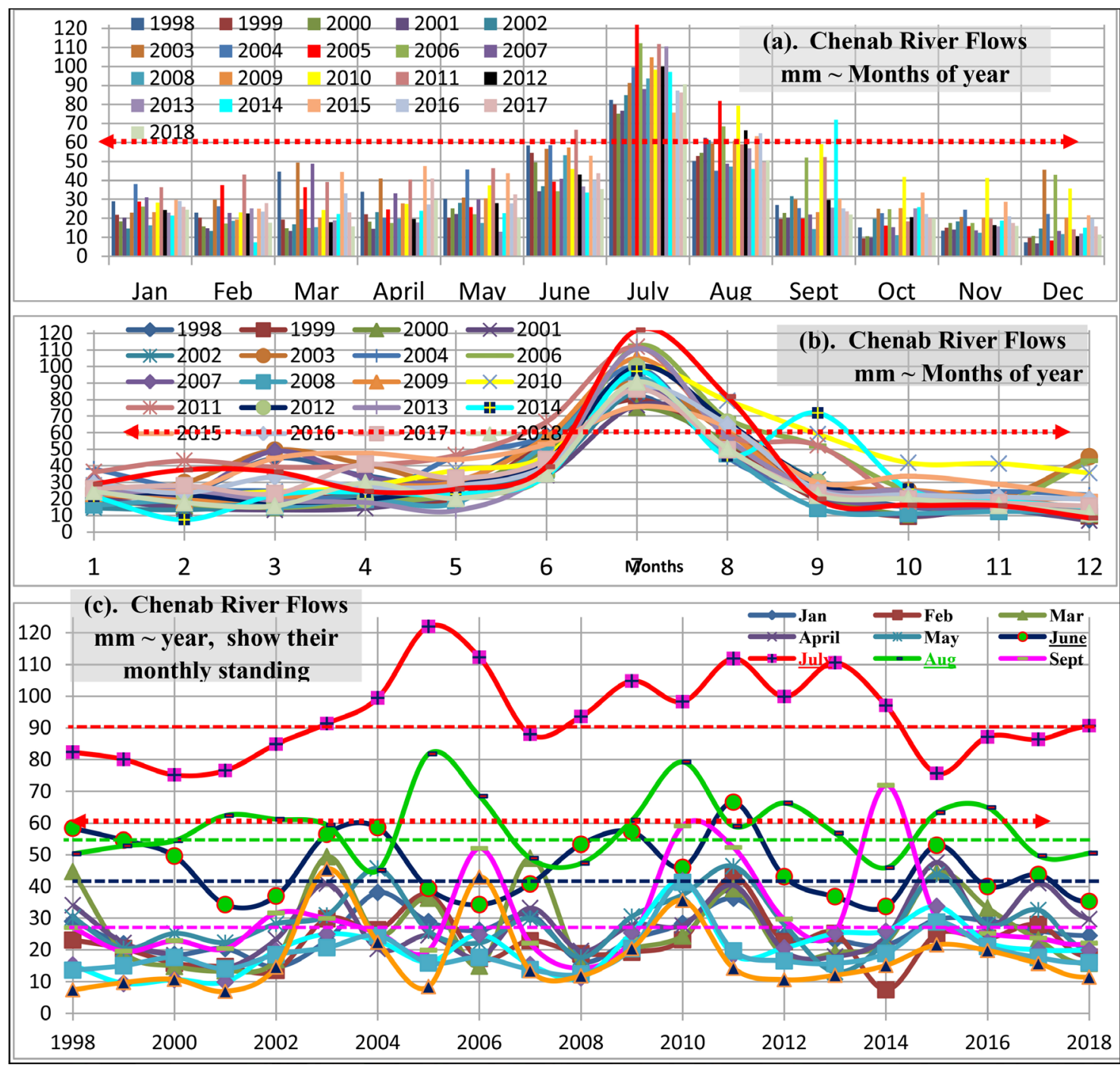

Figure 5. The graphs (a) and (b) are for Chenab river flow versus months showing their yearly month vise trend, while the (c) graph shows the same flow versus year and this clearly show its monthly standing in 21 years span. Its flow in July every year is in extreme flood zone, while August has 8, June and September have only one entry each in extreme flood zone. 


\subsection{Jhelum River Flood Flow}

With the construction of a large dam on this river at Mangla and its storage activity in July, pre-storage preparatory release in June and post storage irrigation needs directed flow release thereafter, thus its flow downstream of Mangla has changed its annual natural flow pattern and made it somewhat smooth well distributed among the needy 6 months (Figure 3 ). In the monsoons season with the heavy rains fall particularly that of July and August, flow in form of large floods is handled by storage and irrigation needs are much reduced due to local rains with yet controlling opportunity due to large storage capacity, that is why there is controlled depression in downstream flow graph (Figure 3, Figure 6)

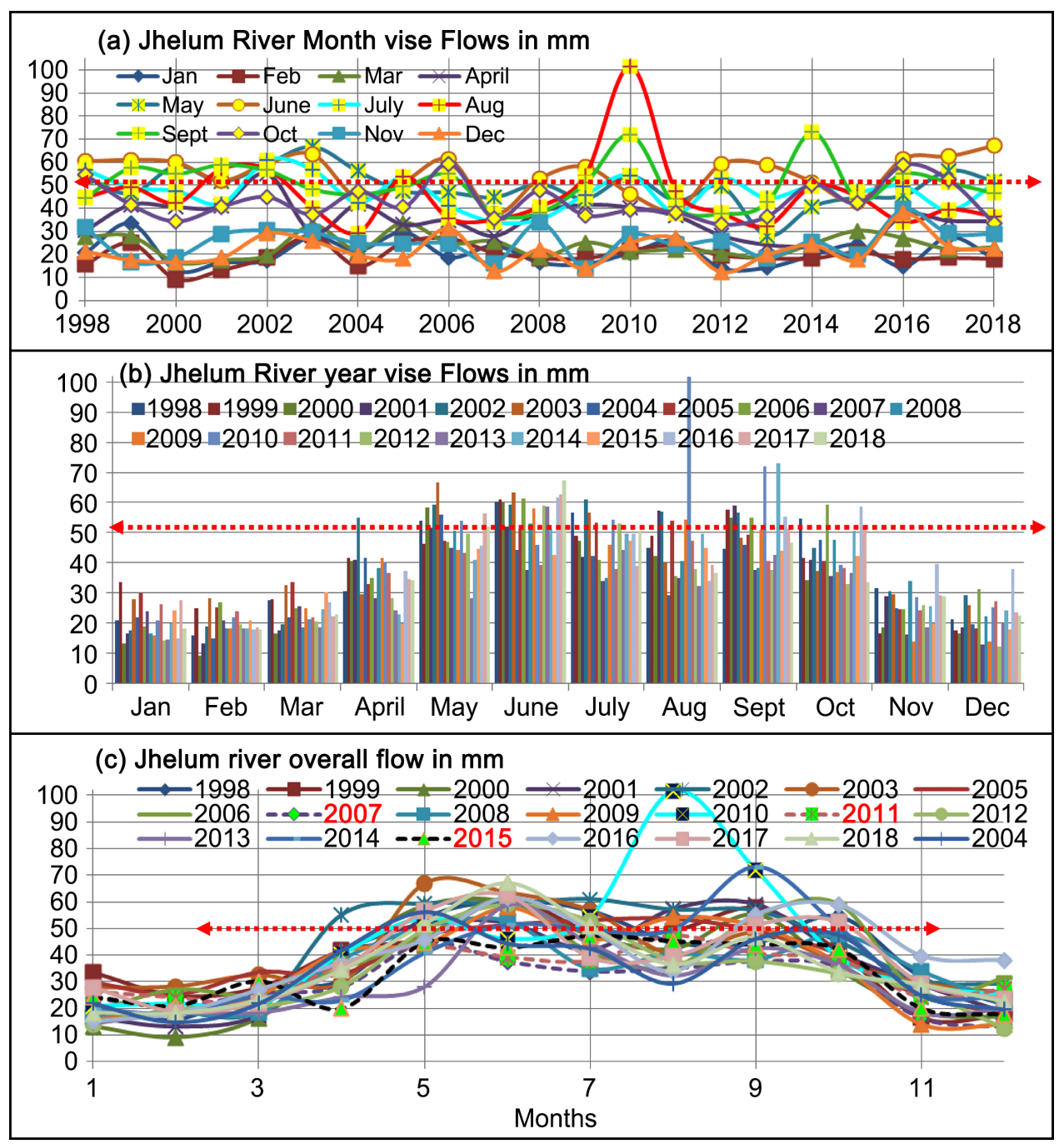

Figure 6. At (a) is the graph of Flow of River Jhelum versus years showing their mutual monthly standings. The 3 years, 2007, $2011 \& 2015$ (i.e. 14.3\%) are of flow much below the average. The (b) is graphs of flow pattern versus months in 21 years showing six months flattened flow due to storage dam operations, more prominent in bars versus month graph. Further storage is still needed as is evident from the flows shooting above red line peak limit, indicated also in (c) above. 
in these two months except a particular case of extraordinary flood flow of August 2010, otherwise it would have followed the trend of Chenab and Ravi rivers. It is leading others rivers by a month (Figure 3 ) due to short route of glaciers early melt and its early monsoon grip. The flow pattern both yearly and monthly running over 21 years span (Figure 6(a)) show peak flows in 2010, 2014, 2018 and 2003 (19\%) indicting decadal time roaming of monsoons. The distribution or supply from the storage has also changed its natural downstream flow pattern (Figure 6(b) \& Figure 6(c)). The four groups of its flows are given below.

1) In Figure 7(a), 5 out of 21 years (24\%) has only one peak (Table 1). The monsoon peak flow duration may be actually for a few days, a weak or two only, but in data record it is stated as sum of the whole month and is mainly due to release from storage.

2) In Figure 7(b), the 6 out of total 21 years (29\%) flow has only 2 peaks in 2 non consecutive months as shown in the graphs and given in Table 1 below.

3) In Figure 7(c), only 5 out of total 21 years (24\%) shown in the graphs have 3 peak flow per year as given in Table 1 .

4) In Figure 7(d), only 01 (i.e. 4.8\%), year 2002 out of total 21 years show flows in the graphs having peak flow in 6 months, while 01 (2010) have four peaks per year (Table 1).

The total monthly peak flow status in these 21 years is as; May has 8 peaks, June 13, July 5, August 5, September 8 and October has only 2 as shown in the table in Figure 10. This confirms the roaming of monsoons in 21 years time domains within May to October. In mutual comparison of maximum peak flows in 21 years from May to October are in order of 66.8, 67.2, 60.9, 101.7, 73.1 and $59.3 \mathrm{~mm}$ respectively, whereas their monthly average in this span is as 49.54 , $54.76,47.10,45.85,50.55$ and $43.1 \mathrm{~mm}$.

Table 1. Jhelum river peak flows.

\begin{tabular}{|c|c|c|c|c|c|c|c|}
\hline Peaks/ & & & & & & & \\
\hline \multirow[t]{2}{*}{0} & 2007 & 2011 & 2015 & & & & \\
\hline & years & 2004 & 2012 & 2013 & 2014 & 2018 & \\
\hline \multicolumn{8}{|c|}{01} \\
\hline & Peak months & 5 & 6 & 6 & 9 & 6 & \\
\hline & years & 1999 & 2001 & 2005 & 2008 & 2009 & 2017 \\
\hline \multicolumn{8}{|c|}{02} \\
\hline & Peak months & 6,9 & 8,9 & 7,8 & 5,6 & 6,8 & 5,6 \\
\hline & years & 1998 & 2000 & 2003 & 2006 & 2016 & \\
\hline \multicolumn{8}{|c|}{03} \\
\hline & Peak months & $5,6,7$ & $5,6,9$ & $5,6,7$ & $6,9,10$ & $6,9,10$ & \\
\hline & years & 1998 & 1999 & & & & \\
\hline \multicolumn{8}{|c|}{$04 / 6$} \\
\hline & Peak months & $4,5,6,7,8,9$ & $5,7,8,9$ & & & & \\
\hline
\end{tabular}




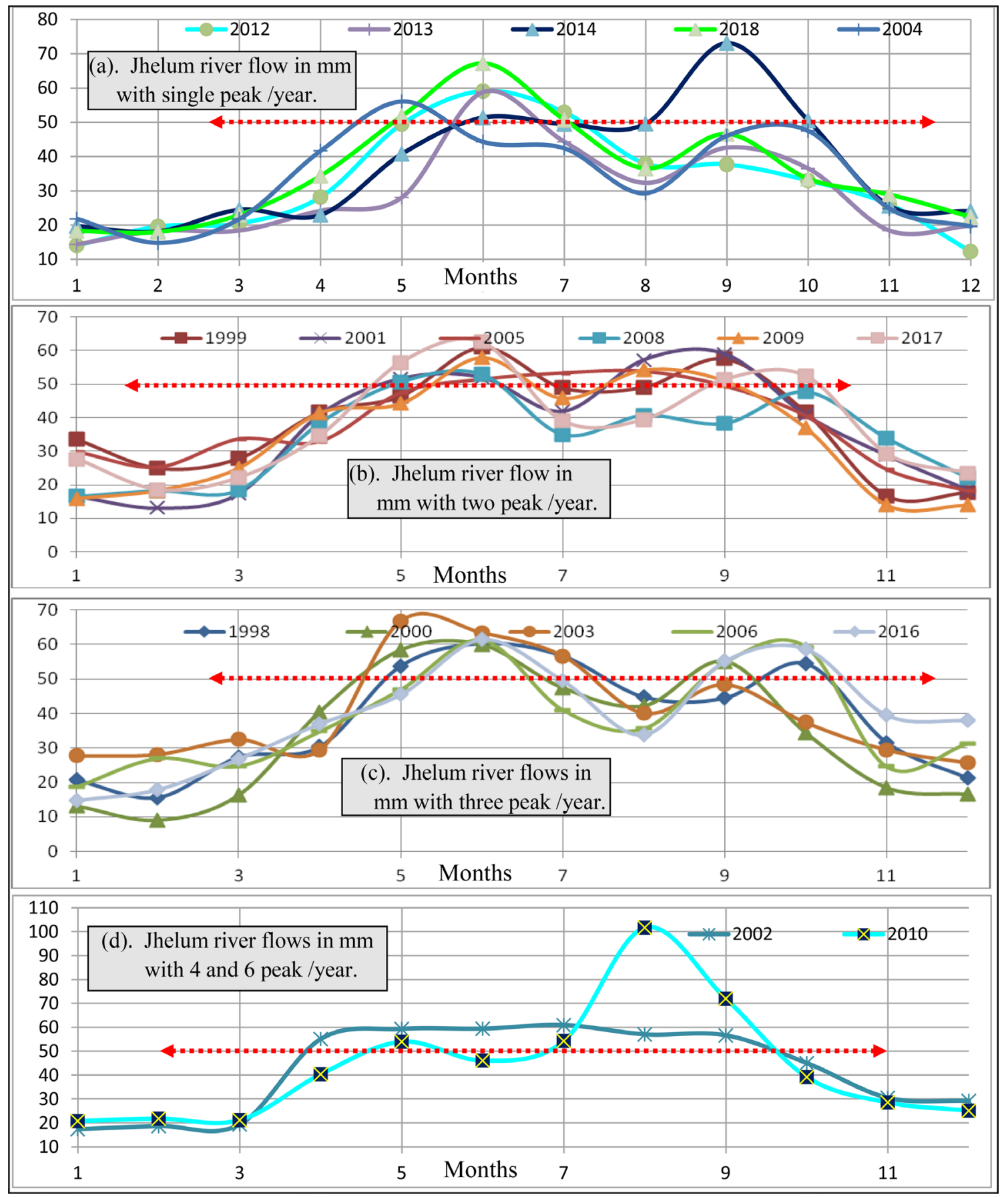

Figure 7. These 4 sets of month vise flow graphs of river Jhelum are. (a) The graph with 5 (24\%) out of 21 years flows having only one peak in a year; (b) The graphs with 6 (i.e. 28.6\%) out of total 21 years flows having 2 peaks in 4 consecutive and 2 non consecutive months; (c) The graphs with only 5 (i.e. 24\%) out of total 21 years flows having 3 peaks in a year; 2 years with consecutive months, while 3 with 2 months gap; (d) The graphs with only 01 (i.e. $4.8 \%), 2002$ out of total 21 year showing flows having peak flow in 6 months, while 01 (2010) have four peaks per year.

\subsection{Indus River Flood Flow}

The construction of Tarbela dam on this river and its storage activity has not changed the flow downstream, as dam storage capacity is extremely small as 
compared to its peak flow (Figure 8). In monsoons, with the heavy rains fall particularly that of July and August, (Figure 8(a), Figure 8(b)) flow in form of large floods is not notably handled by its storage and that is why there is no depression in flow graph in these two months, otherwise it would have followed the trend of Jhelum River. The storage being small, the distribution of flow downstream has also not much changed the natural flow pattern. In both yearly running and monthly pattern over 21 years span (Figure 8(a), Figure 8(b)), the years 1999, 2001, 2005, 2010, 2/2015, 2016, 2017 (38\%), show extraordinary

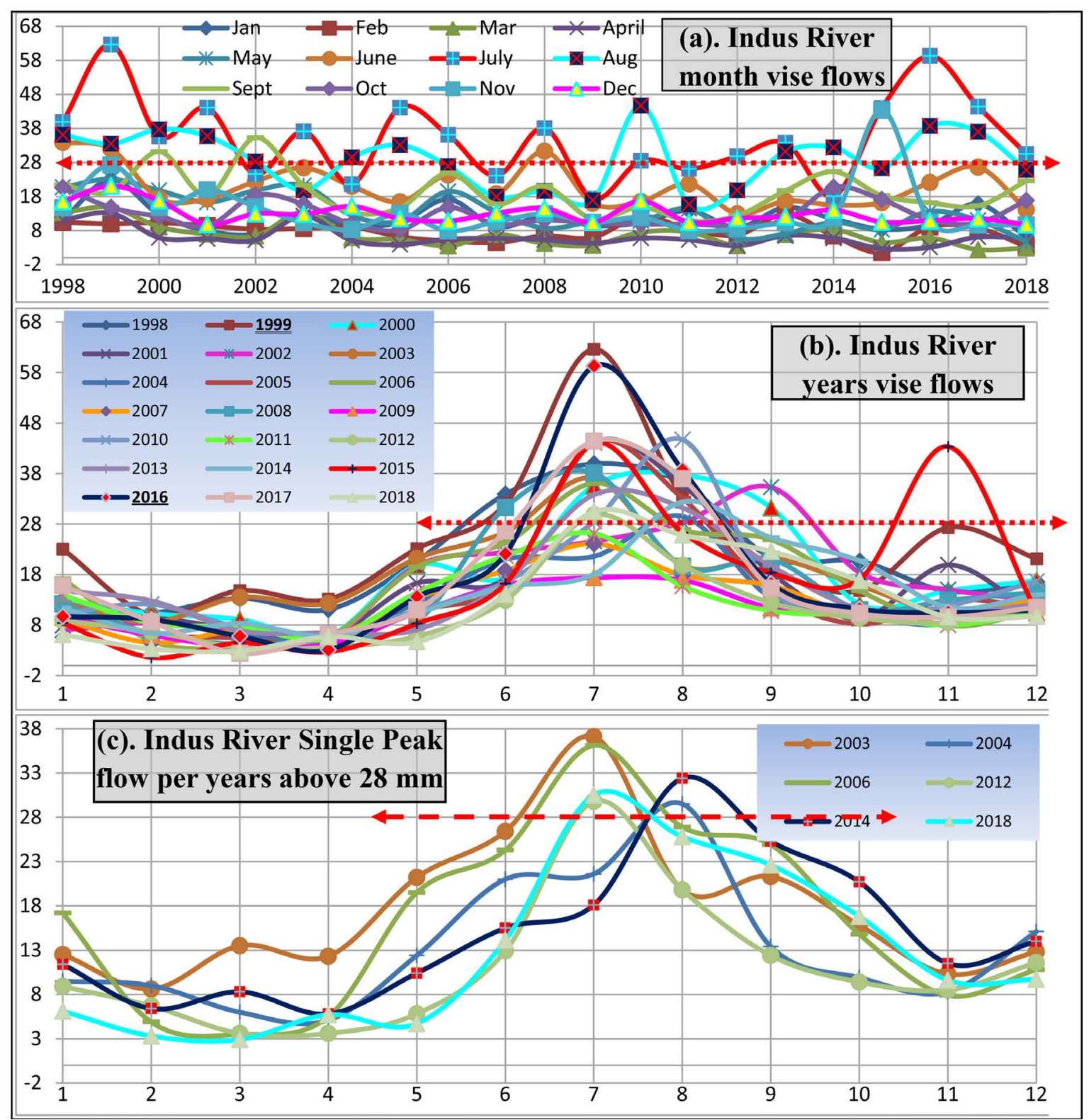

Figure 8. (a) This graph of River Indus Flow versus years showing their mutual monthly stand. There are 6 extra ordinary peak flows in July, one August and one in November in 21 years; (b) The graph shows overall month versus trend of its flow in 21 years; (c) The bottom graph shows its 6 out of total 21 years flows having only one peak flow in a year above $27 \mathrm{~mm}$ minimum flow limit. The peak flow duration may be actually for a few days, a weak or two only, but in data record it stated as sum of the whole month. 
flood flows, supporting decadal time roaming of monsoons. Out of 21 years, 6 (28.6\%, Figure $8(c))$ has only one peak each year, $9(43 \%$, Figure $9(a))$ years have two peaks each year and 3 (14.3\%, Figure 9(b)) year 2007, 2009, 2011 have no peak, while 3 (14.3\%) consecutive years have 3 consecutive months peak flows (Table 2). In these 21 years, monthly peak flow status is that June has 3 , July has 15, August has 12, September has 2 and November has only 1 as shown in the table in Figure 10. This confirms the annual/monthly roaming of monsoons in time within June to November, but mainly in July and August and rarely in others from June to November. In mutual comparison of maximum peak flows in 21 years are in order 33.9, 62.6, 44.7, 35.3, 20.7 and $43.3 \mathrm{~mm}$ respectively for June to November, whereas their monthly average is as 20.92, $35.23,28.89,19.22,12.93$ and $13.72 \mathrm{~mm}$ respectively. The data presented in [9] record is sum of the month, while actually this flood flow may be generally of a 10 - 20 days, particularly in single peak years and nonconsecutive months in multiple peaks in a year.

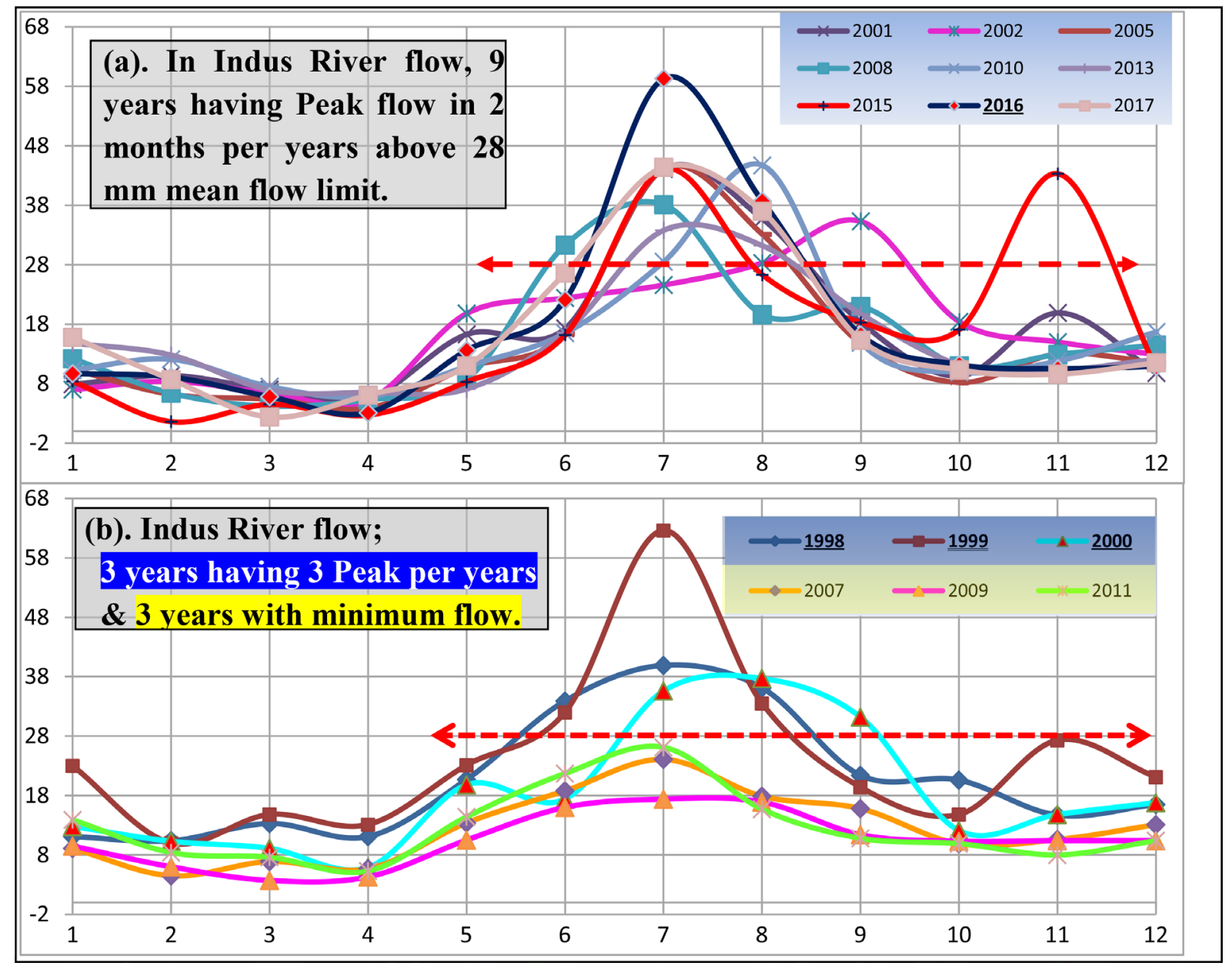

Figure 9. The above two sets of month vise flow graphs of river Indus are for. (a) Top one, for 9 out of total 21 years flows showing the graphs having 2 peaks in 2 months; (b) The bottom one, only 3 out of total 21 years showing flows in the graphs having 3 month peak flow in a year and 3 below the minimum limit. 
Table 2. Indus river peak flows.

\begin{tabular}{|c|c|c|c|c|c|c|c|c|c|c|}
\hline Peaks/yea & & & & & & & & & & \\
\hline 0 peak & years & 2009 & 2011 & 2013 & & & & & & \\
\hline & years & 2003 & 2004 & 2006 & 2012 & 2014 & 2018 & & & \\
\hline & \multicolumn{10}{|c|}{01} \\
\hline & years & 2001 & 2002 & 2005 & 2008 & 2010 & 2013 & 2015 & 2016 & 2017 \\
\hline 02 & Peak months & 7,8 & 8,9 & 7,8 & 6,7 & 7,8 & 7,8 & 7,11 & 7,8 & 7,8 \\
\hline & years & 1998 & 1999 & 2000 & & & & & & \\
\hline \multicolumn{11}{|l|}{03} \\
\hline
\end{tabular}

\subsection{The Overall Seasonal Roaming of Monsoons}

The peak flow instances summed up over each month for all the rivers is tabulated and plotted in Figure 10. Excluding Jhelum, all other 3 rivers' flow is concentrated in July. Ravi flood flow is $100 \%$ in recorded span and that is only in July. Chenab flood flow is $100 \%$ in recorded span and is in July along with $38 \%$ in August too. Indus flood flow presence is $71.4 \%$ in recorded span in July along with $57 \%$ in August too. Its total flood absence is 3 years or $14.2 \%$ and thus its total flooding probability is $85.8 \%$ and almost $42.8 \%$ is in both July and August, while rest $43 \%$ is almost solely in month of July. The pattern of Jhelum is different. 3 years (14.2\%) are dry, while $85.8 \%$ has flooding probability. Here July and August flows have $24 \%$ flooding probability, whereas June has $62 \%$, with solely in June only $10 \%$ and combined with others is $52 \%$. Here May and September have $38 \%$ flooding probability. Thus overall roaming of monsoons in so called monsoon season is negated for 6, 5, 4 or even 3 months as can be viewed in graph and table in Figure 10 and discussed above. It is mainly for one month, July (June for Jhelum) and $2^{\text {nd }}$ August only 57\% for Indus, 38\% for Chenab. Jhelum has 62\% occurring probability in June and $38 \%$ in May and September. The stretching peak flow to 5 or 6 month by the WB is against the reality and ignoring most of the flow in July and not being ready to store it within the tiny storage dam and let most of it gone uninterrupted and thereafter storage activity is ridiculous when the demand has surpassed the supply. The supply was maximum in July, monotonically decreasing till December, while demand was minimum in July increasing monotonically till November (Figure 11), thus large storage is needed to manage a suitable and necessary fill in the gap between the two. The actual status and its proper way forward is shown in Figure 11. It may be observed from it that $3 / 4$ th of total storage quantity has to be gained in July and only $1 / 4$ th is possible in August. The September is a region with matching supply and demand, while October, and November are of peak demands above river flow and this gap is to be filled in by the storage. It means that the first 2 months are of 


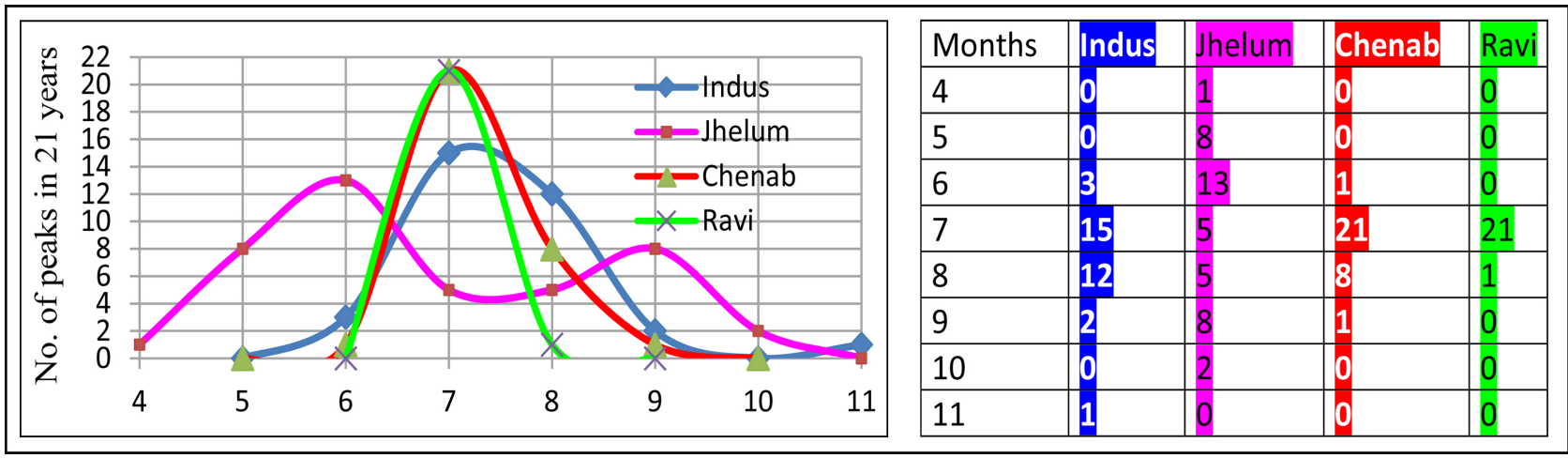

Figure 10. Monthly peak flow status of 4 rivers in 21 years is given above. This indicates almost no roaming, fully concentrated in July, except for Jhelum peaks in June due to large release from Mangla dam for irrigation needs and creation of space for storage of its July inflow. The maximum storage and subsequent irrigation directed release from the storage dam is evident from the graph in August to November. Indus has somewhat comparable flow in August too.

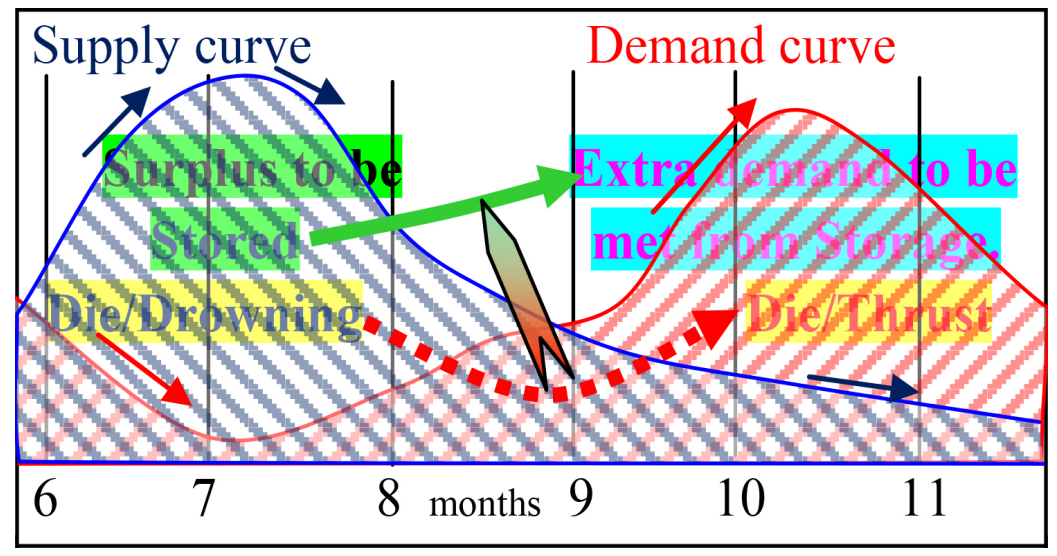

Figure 11. Go by green and store the surplus die neither by drowning nor by thrust.

minimum usage requirements and that too is mostly met with by local rains, rather more than the requirements, thus no reduction in storage estimate due to this is needed at all against the WB ideology. The last 3 months are not supplier to storage rather users and their usage/demand should be added to the storage requirement in place of subtraction against that done by WB. This WB absolutely wrong strategy, opposite to the factual requirements has made one of the Chief Ministers to mourn "we die by drowning when it rains and die by thrust when there is no rain".

\section{Space Roaming of Monsoons}

The intensive Monsoons wondering in catchment areas of different river groups as shown in (Figure 12) are reviewed by three options, 1) trend of flow height $(\mathrm{mm})$ in rivers, 2) flow trend above their average flow height $(\mathrm{mm})$ in the recorded period and 3) from the flow quantity (cubic meters/sec). 


\subsection{Inconsistency in Rivers Flow Height above Average}

Figure 12 shows routes of roaming and precipitation of clouds in catchment area of different rivers and reservoirs of potential dams' sites (pink line covering blue area) for complete storage of extraordinary clouds burst. Dams sites, both large and small, their feeder flood channels, irrigation canals, rain drains, power tunnels required to cope with Global Environment Emergency demands are shown in Figure 12. The catchment area of Indus Rivers System may be divided in somewhat following groups for monsoon space roaming analyses (Figure 12).
a) River Swat, Kabul and Kunar;
b) Rivers Indus and Soan;
c) Rivers Jhelum, Neelam, Kunhar, Chenab, Bunnah, Rohtas;
d) Rivers Ravi and Sutlej.

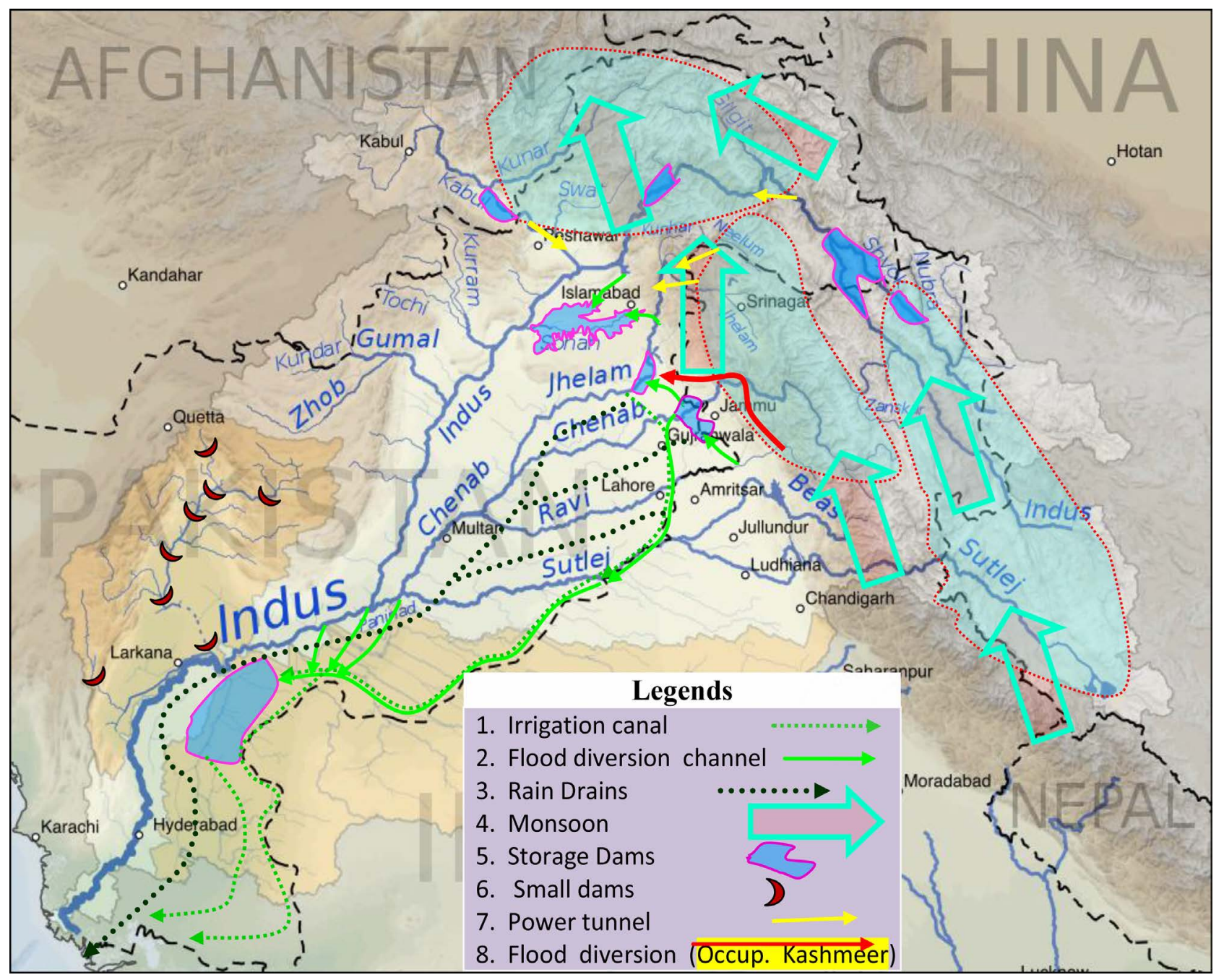

Figure 12. Routes, roaming and precipitation of clouds in catchment area (red dotted line) of different rivers and reservoirs of potential dams' sites (pink line covering blue area) for complete storage of extraordinary clouds burst. Dams sites, both large and small, their feeder flood channels, irrigation canals, rain drains, power tunnels required to cope with Global Environment Emergency demands. 
It should be noted that Chenab and Ravi apparently have no storage sites in Pakistan, thus for flood flow storage, Chenab is grouped with Jhelum for its flood water storage at Rasul through Mrala-Kharian flood diversion channel and Ravi also if a flood diversion channel from Kathua-Jummu-Akhnoor (Occupied Jammu \& Kashmir) as shown red in Figure 12 is allowed. A dam must also be made at BRB/Ravi siphon of 215/217 M Asl (above sea level) height and a flood relief channel for flood safety, regulation and maintenance/recharge of underground water table at Lahore. As can be seen in this figure that Sutlej, Indus and Brahmaputra Rivers at their initiation have catchment areas in Tibet-China very close to each other and there are instances when these all are flooded by monsoon downpour in this area. The flood water of Sutlej can be stored in Jamrao dam by its two diversion channels; one from Head Sulemanki along the Indian boarder to Chulistan along with the irrigation canal for Chulistan and upper Thar and then to Jamrao via Mazar Dadi Karam Khatoon. This is the most wanted and most effective in view of GHT and NAH control. The $2^{\text {nd }}$ one is from Punjnand to Mazar Dadi Karam Khatoon and then to Jamrao through the track same as 1 . The Ravi, Chenab and Jhelum overflow as well as managed flow may share $2^{\text {nd }}$ channel also, but another for Indus from Khan Bela to Mazar Dadi Karam Khatoon and $4^{\text {th }}$ from Guddo barrage to Jamrao via Allah Obhayo Mahr are also required to safely divert the flood water loads shared by all the four as far as possible. Table 3 and Figure 13 show the flow height (not to be mutually compared for flow quantity) above their mean flows, with highlighted flows below average and none highlighted for the above clearly show the huge support to the paradigm of space monsoons roaming.

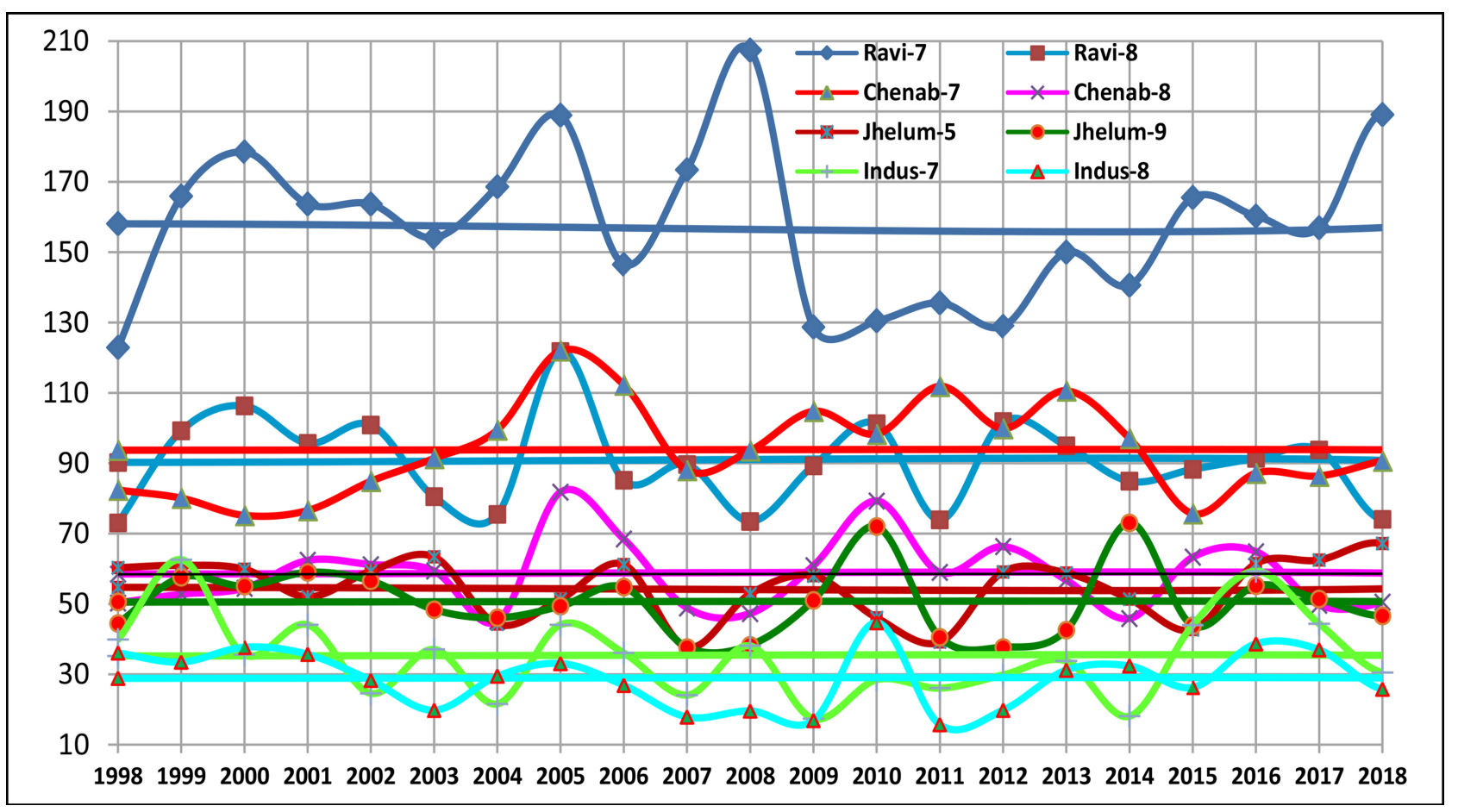

Figure 13. Peak Flow in $\mathrm{mm}$ of four rivers in their peak months relative to their average over 21 years span. 
Table 3. Space roaming of monsoons directed rivers flow of 21 years*.

\begin{tabular}{|c|c|c|c|c|c|c|c|c|}
\hline \multirow{2}{*}{ Year } & \multicolumn{4}{|c|}{$\begin{array}{l}\text { July (June. for Jhelum) flows with } \\
\text { respect to average of } 21 \text { Years }\end{array}$} & \multicolumn{4}{|c|}{$\begin{array}{l}\text { August (Sept. for Jhelum) flows with } \\
\text { respect to average of } 21 \text { Years }\end{array}$} \\
\hline & Ravi & Chenab & Jhelum & Indus & Ravi & Chenab & Jhelum & Indus \\
\hline 1998 & B & B & A & $\mathrm{A}$ & B & B & B & A \\
\hline 1999 & A & B & A & A & A & B & A & A \\
\hline 2000 & A & B & A & A & A & B & A & A \\
\hline 2001 & A & B & B & A & A & A & A & A \\
\hline 2002 & A & B & A & A & A & A & A & B \\
\hline 2003 & B & B & A & $\mathrm{A}$ & B & A & B & B \\
\hline 2004 & A & A & B & B & B & B & B & A \\
\hline 2005 & A & A & B & A & A & A & B & A \\
\hline 2006 & B & A & A & A & B & A & A & B \\
\hline 2007 & A & B & B & B & B & B & B & B \\
\hline 2008 & $\mathrm{~A}$ & B & B & A & B & B & B & B \\
\hline 2009 & B & $\mathrm{A}$ & $\mathrm{A}$ & B & B & A & B & B \\
\hline 2010 & B & A & B & B & A & A & A & A \\
\hline 2011 & B & A & B & B & B & A & B & B \\
\hline 2012 & B & A & A & B & A & A & B & B \\
\hline 2013 & B & A & A & B & A & B & B & $\mathrm{A}$ \\
\hline 2014 & B & A & B & B & B & B & A & A \\
\hline 2015 & A & B & B & A & B & A & B & B \\
\hline 2016 & A & B & A & A & B & A & A & A \\
\hline 2017 & A & B & A & A & A & B & A & A \\
\hline \multirow[t]{2}{*}{2018} & A & B & A & B & B & B & B & B \\
\hline & $\begin{array}{c}A=12 \\
B=9\end{array}$ & $\begin{array}{l}A=9 \\
B=12\end{array}$ & $\begin{array}{c}\mathrm{A}=12 \\
\mathrm{~B}=9\end{array}$ & $\begin{array}{c}A=12 \\
B=9\end{array}$ & $\begin{array}{l}\mathrm{A}=9 \\
\mathrm{~B}=12\end{array}$ & $\begin{array}{l}\mathrm{A}=9 \\
\mathrm{~B}=12\end{array}$ & $\begin{array}{l}A=9 \\
B=12\end{array}$ & $\begin{aligned} A & =11, \\
B & =10\end{aligned}$ \\
\hline
\end{tabular}

Note: * $A$ " is for value above and " $\mathrm{B}$ " for below average flow in 21 years time span. 


\subsubsection{Review of Flow Sets}

In the above stated table for each of the two maximum flow months, there are 21 sets, for each month in 21 years and 42 for both the two peak flow months. Thus from out of 42 sets of four rivers flows in 21 years it is quite clear that:

1) There are only two sets (4.76\%), one each in each of two years that have flow above the average in all the four rivers and that is only in August and never in the maximum flow month of July. (red background)

2) There are 13 sets (30.95\%) with flows only in three river above average, 7 for July and 6 for August. (reddish background)

3) There are 14 sets (33.33\%) with two river flows above average, 10 for July and 4 for August. (green background)

4) There are 10 sets $(\mathbf{2 3 . 8 1 \% )}$ ) with only one river flow above average, 4 for July and 6 for August. (cyan background)

5) There are only three sets $(\mathbf{7 . 1 4 \% )}$, one each in a year, that have flow below the average in all the four rivers and that is again only in August and never in the maximum flow month, July. (blue background).

It means that in general monsoons rainfall roaming concentration is $24 \%$ in only one river catchment area, $33 \%$ in two, $31 \%$ distributed in the three, and only $5 \%$ distributed in all the 4 rivers catchment areas and that is only in August and never in the maximum flow month, July, as shown in Figure 14. This again highly supports the paradigm of space roaming of monsoons. Their relative stature can be seen in Figure 14.

Also the flow of Ravi has 12 above and 9 below average in July and reverse in August, Chenab has 9 above and 12 below average in both July and August, Jhelum has 12 above and 9 below average in June and reverse in September and Indus has 12 above and 9 below average in July and 11 above and 10 below average in August. This means that July above average flow of rivers is more in numbers and less for below average, while reverse is true for August.

\subsubsection{Seesaw in Rivers Ravi and Chenab Flows}

Out of 42 sets, 27 set of both Ravi and Chenab are of opposite sense or seesaws behavior, while 15 have matching flow trend; 8 (July $=2$, Angst $=6$ ) sets of below and 7 (July $=2$, Angst $=5$ ) of above average. Their July flow is generally stabilized;
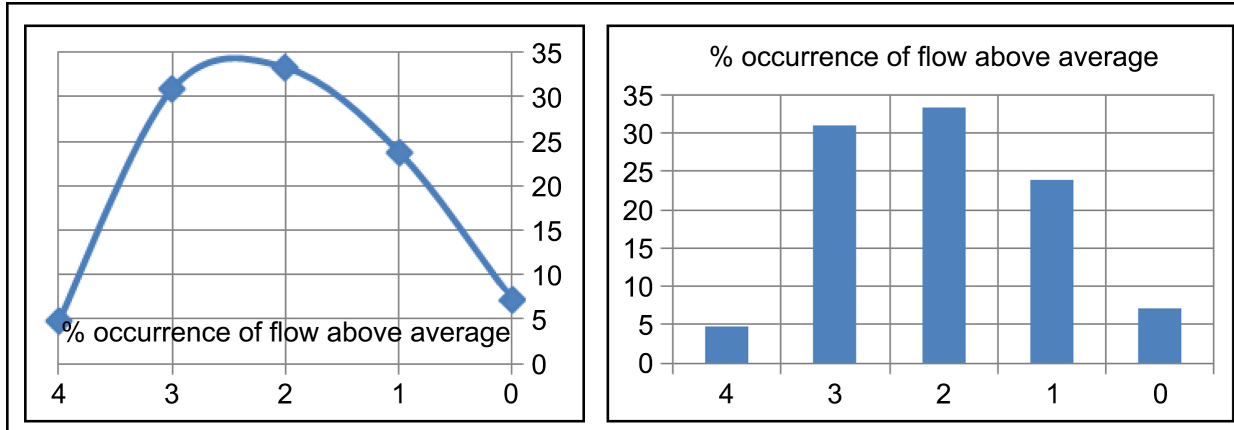

\begin{tabular}{|c|c|}
\hline Rivers & $\begin{array}{c}\text { \% occurrence of } \\
\text { flow above } \\
\text { average }\end{array}$ \\
\hline 0 & 7.14 \\
\hline 1 & 23.81 \\
\hline 2 & 33.33 \\
\hline 3 & 30.96 \\
\hline 4 & 4.76 \\
\hline & 100 \\
\hline
\end{tabular}

Figure 14. Trend of Percentage flow occurrence above average in 4, 3, 2, only one rivers and none at all in 2 peak months. 
same pattern for continuous 6 years with Ravi lead, 2 sets for continuous 4 years with Chenab lead, 2 sets of continuous 2 years with one equal and one Chenab lead. This again confirms the paradigm of space roaming of monsoons.

\subsubsection{Mismatching Flows in Rivers Indus and Chenab}

Out of 42 sets, 31 are of opposite sense in flows of Indus and Chenab, while 11 are matching. In July, out of 21, two set of 6 continuous years, one with Indus and one with Chenab lead and one set of 3 continuous years with Indus lead, while in August only one set of 3 continuous year are stable in flows with Indus lead. This again highly supports the paradigm of space roaming of monsoons.

\subsubsection{Matching Flows in Rivers Indus and Jhelum}

Excluding 14 sets of opposite sense, all other 28 sets of Indus and Jhelum flows are matching and stabilized for 3 sets of 3 years and thus mismatching with Chenab. This again supports space roaming paradigm of monsoons.

\subsection{Space Roaming by Flow Height Trend}

Figure 15 shows the monthly general flow while their mutual stature comparison is shown by red vertical trend line with values of their scales for June, July, August, September and October as 90, 210, 125, 75 and $65 \mathrm{~mm}$ respectively. Their approximate flow quantity stature using "Manning Equation" [14] may be of order of $1810,7433,3130,1336$, and $1052 \mathrm{~mm}^{3} / \mathrm{sec}(24 \%, 100 \%, 42 \% 18 \%$ and $14 \%)$ with some common multiple. This shows much dominant stature of July and comparatively less than $43 \%$ for August, all other are much smaller, particularly that of October. In view of Figure 15, and Table 4, the analysis of these is given below.

\subsubsection{Increasing Flow Trend in all Rivers}

Out of 100 sets for 5 months over 20 years, there are only 12 set (red) in which all the four rivers have rising trend. That means only $12 \%$ is the probability of flood flow in all the rivers. However, if only 2 peak flow months are considered, only 2 are in July and 2 in August, which are worth consideration and all other 8 are of small stature. Thus actually only $4 \times 100 / 40=10 \%$ is the probability of flood flow in all the rivers when considering only 2 peak flow months.

\subsubsection{Increasing Flow Trend in 3 Rivers}

Out of 100 sets, there are only 20 set in which 3 rivers have rising trend. This means that only $20 \%$ is the probability of flood flow in 3 rivers. However, only 5 in July and 5 in August, which are worth consideration and all other 10 are of small stature. Thus actually only $10 \times 100 / 40=25 \%$ is the probability of flood flow in 3 rivers when considering only 2 peak flow months.

\subsubsection{Increasing Flow Trend in 2 Rivers}

Out of 100 sets, there are only 32 set in which 2 rivers have rising trend. That means 32 probability of flood flow is in only 2 rivers. However, only 9 are in July and 5 in August, which are worth consideration and all other 18 are of small stature. 


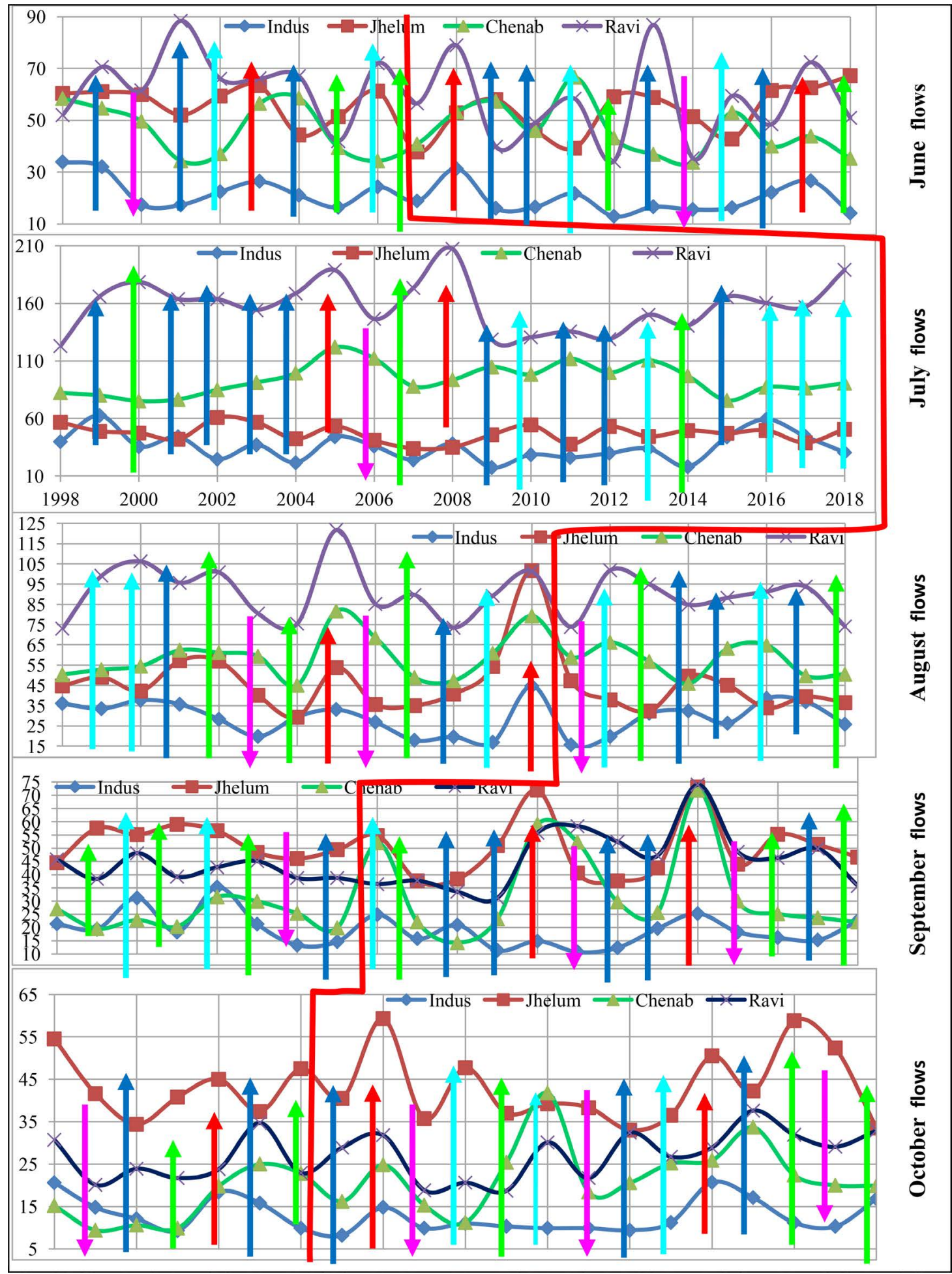

Figure 15. Flow pattern of 4 rivers of Indus river system is shown above. The monthly general flow stature comparison is shown by red vertical trend line across all the 5 months with values for June, July, August, September and October as 90,210, 125, 75 and $65 \mathrm{~mm}$ respectively. This shows the dominancy of flow in July and August and of least consideration for others. Out of 100 sets of 5 months in 20 years, 12 (red arrows) sets show flood flow in all rivers, 20 (cyan arrows) sets show flood flow in 3 rivers, 32 sets (blue arrows) show flood flow in 2 rivers, 23 sets (green arrows) show flood flow in only one river, while 13 (pink down arrows) show decreasing trend in all rivers. 
Table 4. Flow trend of Indus river system.

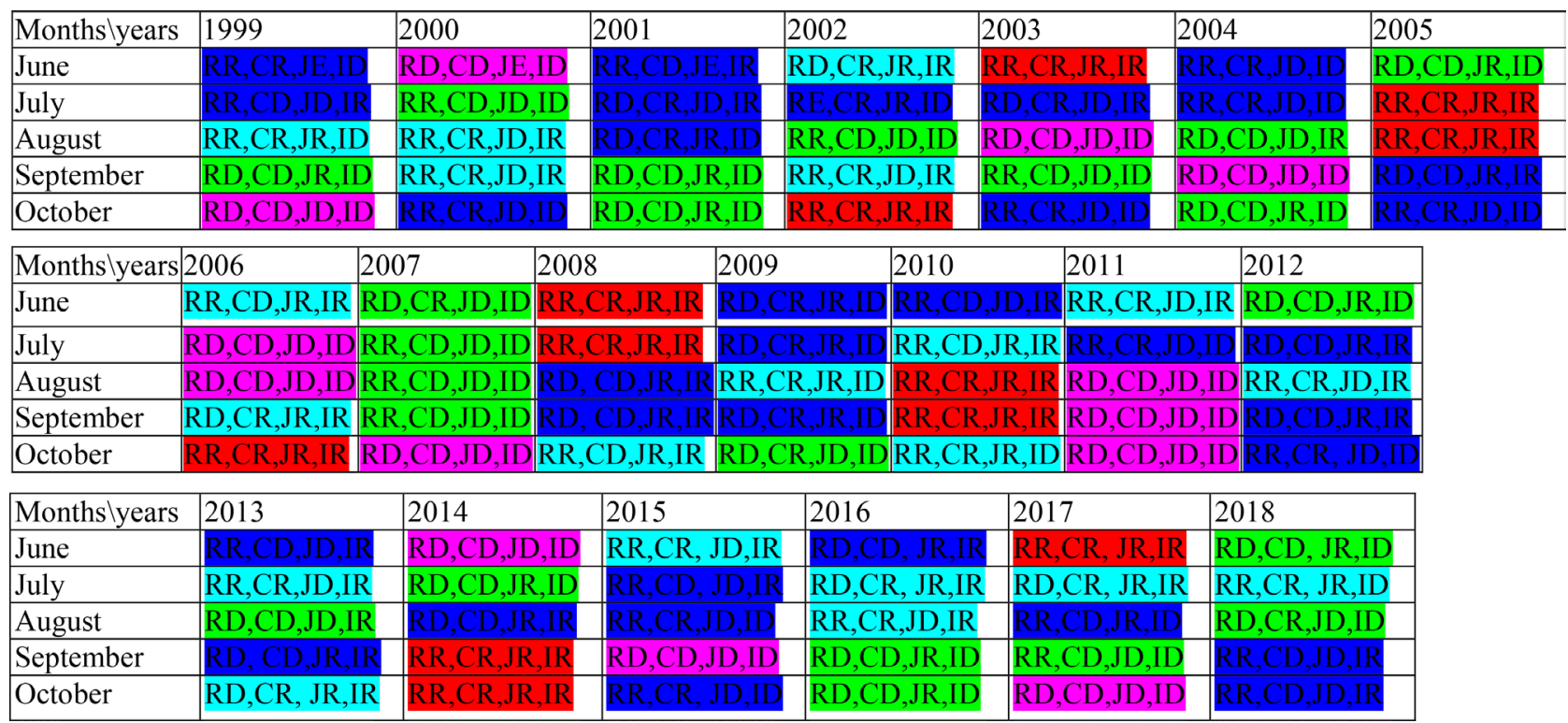

Note: The characters on left R, C, J, I stand for Ravi, Chenab, Jhelum and Indus rivers respectively, while on right side character R stand for rising up flow and $\mathrm{D}$ for depressing flow.

Thus, actually only $14 \times 100 / 40=35 \%$ is the probability of flood flow in 2 rivers when considering only 2 peak flow months.

\subsubsection{Increasing Flow Trend in only 1 Rivers}

Out of 100 sets, there are only 23 set in which only 1 river have rising trend. That means that only $23 \%$ probability of flood flow is in only 1 river. However, only 3 are in July and 5 in August, which are worth consideration and all other 15 are of small stature. Thus actually only $8 \times 100 / 40=20 \%$ is the probability of flood flow in only 1 river when considering only 2 peak flow months.

\subsubsection{Below Average Flow Trend in all Rivers}

Out of 100 sets, there are 13 set (pink arrow) in which all rivers have Below Average trend. That means only $13 \%$ probability of low flow in all rivers. However, only 1 is in July and 3 in august, are worth consideration and all other 9 are in low flow months. Thus actually only $4 \times 100 / 40=10 \%$ is the probability of low flow in all rivers when considering only 2 peak flow months.

\subsubsection{Overall Flow Height Trend}

The above stated trend for 5 months and 2 peak flow months is shown below in bar chart (Figure 16), for better mutual comparison and a solid proof of space roaming of monsoons. The trend of all the 4 rivers in 2 and 5 peak months, from June to October during 21 years from 1998-2018 shows the space roaming of monsoon rainfall. The probability of $20 \%-23 \%$ all monsoon loads discharged in one river group is too much critical, even $32 \%-35 \%$ in 2 rivers is very critical too and these dictate heavily to have maximum possible storage on each river 


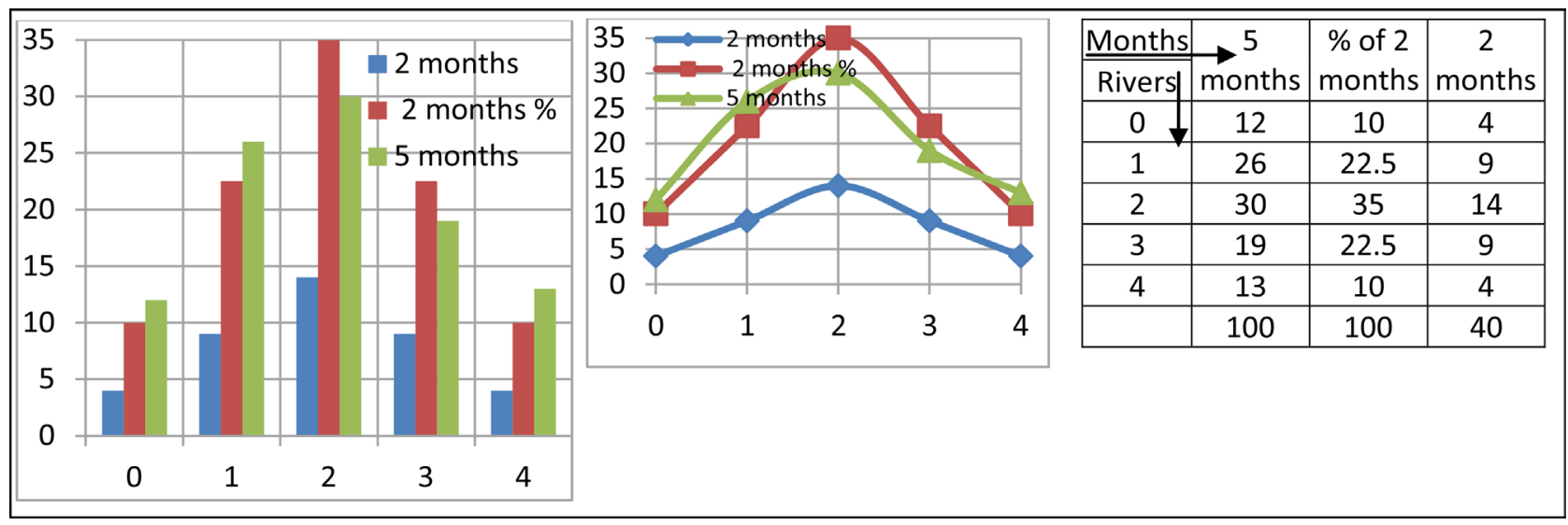

Figure 16. Overall trend of Flow in only one, 2, 3 and all the 4 rivers when considering over five months and when considering only in 2 peak flow Months along with minimum flow in all rivers.

along with quick strategy to share the flood flow load with others. The nature has provided this opportunity in shape of Jamrao dam with large storage to release the pressure on all upstream dams.

\subsection{Inconsistency in Rivers' Flow Quantity Trend}

Figure 17 and Table 5 shows the flow quantity trend of all the 4 rivers during 21 years from 1998-2018. As per its Categorization reported by [9] are in all 21 years span,

1) Flood reaching 25 years record, there are only 5 instances of crossing this limit in 5 year, all in a single river at a time. This confirms space roaming.

2) There are 8 years crossing of 10 years Flood record with only one instant (2014) of flood in two rivers, Jhelum and Chenab and 7 years with flood in only one river. This again confirms space roaming.

3) There are 8 years crossing 5 years Flood record limit with only 2 instances of year 2015 and 2018 of flood in only two rivers and 6 years with flood in only one river. This again confirms space roaming.

4) Flood reaching 1.5 years record, there are only 4 instances in years 1998, 2003, 2004 and 2012 with flood in three rivers, 7 instances in years 1999, 2001, 2002, 2006, 2008, 2013 and 2016 (see Table 5) with flood in only two rivers and 10 instances with flood in only one river. This again confirms space roaming.

The bar chart of above and table are shown in Figure 18. In 25 years record flood, only single river with $24 \%$ occurring is present; in 10 years record flood, single river with $33 \%$ occurring along with $5 \%$ of 2 rivers; in 5 years record flood, single river with $28.5 \%$ occurring along with $9.5 \%$ of 2 rivers; in 1.5 years record flood single river with $47.7 \%$ occurring along with $33.3 \%$ of 2 rivers and $19 \%$ of 3 rivers are present. In these all floods categories, 4 rivers flood together is nowhere, 3 rivers together is only in 1.5 years flood record with only $19 \%$ presence, otherwise this too is nowhere in higher floods categories, 2 rivers have minor stature and absent in 25 years category. This strongly confirms the spatial roaming of monsoons. The rivers Ravi and Chenab have almost critical foods 


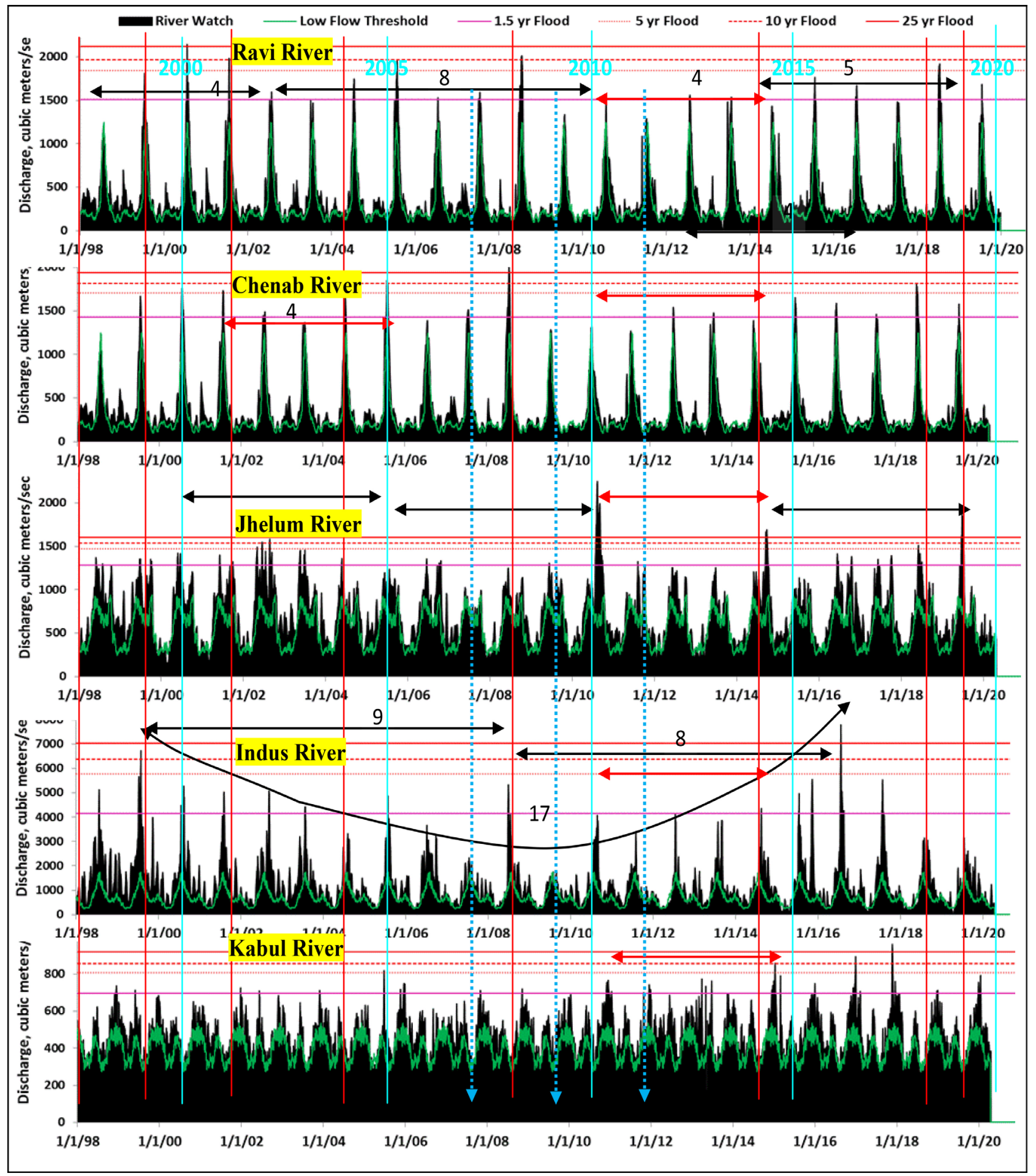

Figure 17. Flow of 5 rivers of Indus Rivers system in a 21 years' time span placed together for mutual flood flow matching and comparison. Sizeable dam on river Jhelum has flattened the flow and reduced the gaps and their depths in between peak flows, while water supply from Jhelum and Indus through feeder link canals has reduced the depth of gap in flow of Rivers Ravi and Chenab. The Kabul River is much smooth, has small gaps, both in width and depth with low flow supported by melting of glaciers. The cyans are time vertical lines. The 3 blue dotted lines are indicative of low flow years. The red and cyan vertical lines may be followed for flow comparison among different rivers. The 4, 5, 8 years gap between flows show their response to Venus lapses and general trend of flow shown by curve of 17 years may be patched with 18.6 years cycle of nodal precession of moon. 5 years shown red arrows corresponds 5 years peak floods cluster. 
Table 5. Monsoon floods space roaming.

\begin{tabular}{|c|c|c|c|c|c|c|}
\hline \multirow{2}{*}{ S/No } & \multirow{2}{*}{ Comparison bases } & \multicolumn{4}{|c|}{ Year of flood flow in Rivers } & \multirow{2}{*}{ Comments } \\
\hline & & Ravi & Chenab & Jhelum & Indus & \\
\hline 1 & Flood reaching 25 years record & 2000 & - & $2,10,19$ & 16 & None match \\
\hline 2 & Flood reaching 10 years record & $01,5,8$ & $7,11,14$ & 14,17 & 99 & No. match except in 14 \\
\hline 3 & Flood reaching 5 years record & 18 & $5,10,12,13,19$ & 15,18 & 2000, 15 & $\begin{array}{c}\text { None match except } 2 \text { in } \\
\text { the year } 15,18\end{array}$ \\
\hline 4 & Flood reaching 1.5 years record & $\begin{array}{c}99,2,3,4,6,7 \\
10,12,13,15,19\end{array}$ & $98,4,8,9,16,18$ & $\begin{array}{l}99,2000, \\
6,11,12,\end{array}$ & $\begin{array}{l}8,1,2,3,5 \\
12,13,17\end{array}$ & $\begin{array}{l}\text { None match except 1) } 2 \text { in the } \\
\text { years } 99,1,2,6,8,13,16 \text { and } \\
\text { 2) } 3 \text { in } 98,3,4,12\end{array}$ \\
\hline
\end{tabular}

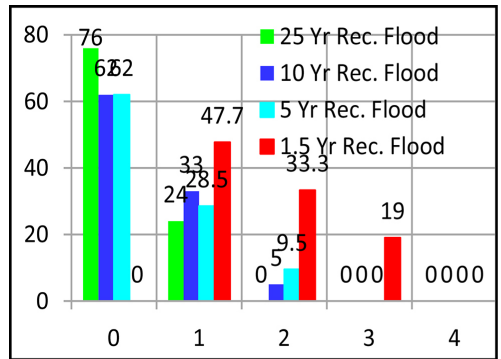

\begin{tabular}{|l|l|l|l|l|l|}
\hline Floods Records/Rivers & 0 & 1 & 2 & 3 & 4 \\
\hline 25 Yrs. Flood Record. & 76 & 24 & 0 & 0 & 0 \\
\hline 10 Yrs. Flood Record. & 62 & 33 & 5 & 0 & 0 \\
\hline 5 Yrs. Flood Record. & 62 & 28.5 & 9.5 & 0 & 0 \\
\hline 1.5 Yrs. Flood Record. & 0 & 47.7 & 33.3 & 19 & 0 \\
\hline
\end{tabular}

Figure 18. Percentage of floods of 4 categories in 4 rivers is presented above. All 4 rivers together are never in any category; 3 rivers is $19 \%$ in only 1.5 Yrs; 2 rivers is $5 \%, 9.5 \%$, $33.3 \%$ in lower 3 category and only one river is $24 \%, 33 \%, 28.5 \%$ and $47.7 \%$ respectively in all 4 categories from top.

almost every year (97\% probability), while Jhelum too have these every year except years 2007 and 2019 (90\% probability), whereas Indus has this in 14 years i.e. $67 \%$ probability. All these confirm the spatial roaming of Indian Monsoons. The flat coverage of Jhelum flow is due to supply of water from its storage dam, both pre and post monsoon for agricultural requirement and for creation of space for incoming July and August flow in its dam. The depression in its July and August flow downstream of dam is due to dam's large storage control of flow under irrigation demand diminished by monsoon rains. In Indus very small proportion of water is stored in its dam and hence its storage or supply shows thin coverage, in other words wider and deeper gaps in flows of Indus. The relatively wider coverage of Chenab and Ravi is due to supply from feeder link canals. The decadal roaming of monsoons is discussed below.

\section{Monsoon Roaming versus Decadal Time}

Figure 1(a) shows the flow fluctuations of Indus Rivers System over the years roaming of Monsoons. Its Figure 1(b) part show mutual floods flow comparison and also with their own average/mean and low flow thresholds elaborating over the years or decadal flow roaming. Some of Historic Record of Peak Monsoon Roaming in time and space is pointed out just for support of this paradigm.

1) The 1955 worst flood was in Ravi with heavy rain fall mainly in catchment 
Area of Ravi River (river group d) [15].

2) The 1973, 1988, 2005, 2014 floods were mainly in Chenab river catchment area (group c).

3) The 1992, 2014, 2015, 2017 floods were observed mainly in Jhelum River (group c) [16] [17].

4) 2010 flood was in Kabul, Swat and Indus (groups a \& b) as shown in Figure 19.

5) 1994 flood was in Indus and Sutlej (group b \& d) [15].

6) Srinagar Valley (Jhelum River) has $67 \%$ probability of 4 year cyclic peak monsoons rains [8].

7) Record of Critical flood in Pakistan by Wapda/Pakistan [18] [19] [20] [21] analyzed in [8].

The above "number 7" showed a multi-cyclic occurrence with main 18.6 and 37 years cycles (two 18.6 cycles together, one with higher and $2^{\text {nd }}$ with lower flow). This showed the frequency trend of floods in Pakistan with perhaps alternate 3 and 5 years cluster of extreme floods and $13-14$ years cluster of normal floods or moderate rivers flows. These 13 - 14 years may have about 3 - 4 year minimum river flow in the middle and 4 - 5 year moderate floods around this dry season within 18.6 semi cycle. It is also evident from graph (Figure 2(a)) of un-controlled flood water going to Arabian Sea [10] [11] [12] from Kotri Barrage. The cycle of trend line again confirms the paradigm arrived at from analysis in [8]. If, it were managed to regulate this with continuous regulation over the 34 years span, then additional 50 MAF per year would have been available for further dispersal for GHT, irrigation and power output. Then 277 MAF minimum storage demand would have to be in 1996 (Figure 2(b)). However, additional 40 MAF per year dispersal with 497 MAF storage (Table 6) seems much better choice to smoothly meet draught demands. These all are patched with lunar nodal procession cycle of 18.61 years when moon is closest to the earth's northern hemisphere in its every second cycle of 18.61 years [8]. In the next cycle it will be on the southern side and hence comparatively dry season during this cycle on the northern side. Also the dry season is follower of 3 - 4 years heavy rainy cluster, hence long storage management $(18.5+3+$ $13=34$ years) will be needed. All these confirm the roaming of Indian monsoon in the multi-years Domain. This confirms generally the roaming of rainfall outburst in different years as well as in different river groups. Thus each river group should be able to handle complete storage of its ever recorded maximum flood flow. The seasonal roaming is not much to worry about being mostly concentrated in July. Space roaming demands the ability to handle maximum flow in all rivers groups. The decadal monsoons roaming is directed by moon precession of 18.61 years cycle and is most critical along with 3, 4, 5 year's cycle dictated by Venus. The 18.6 and 37 years cycles have most stringent and extremely wide variation, both in time and flow quantities. This dictates huge storage, intelligently managed flow regulations. 


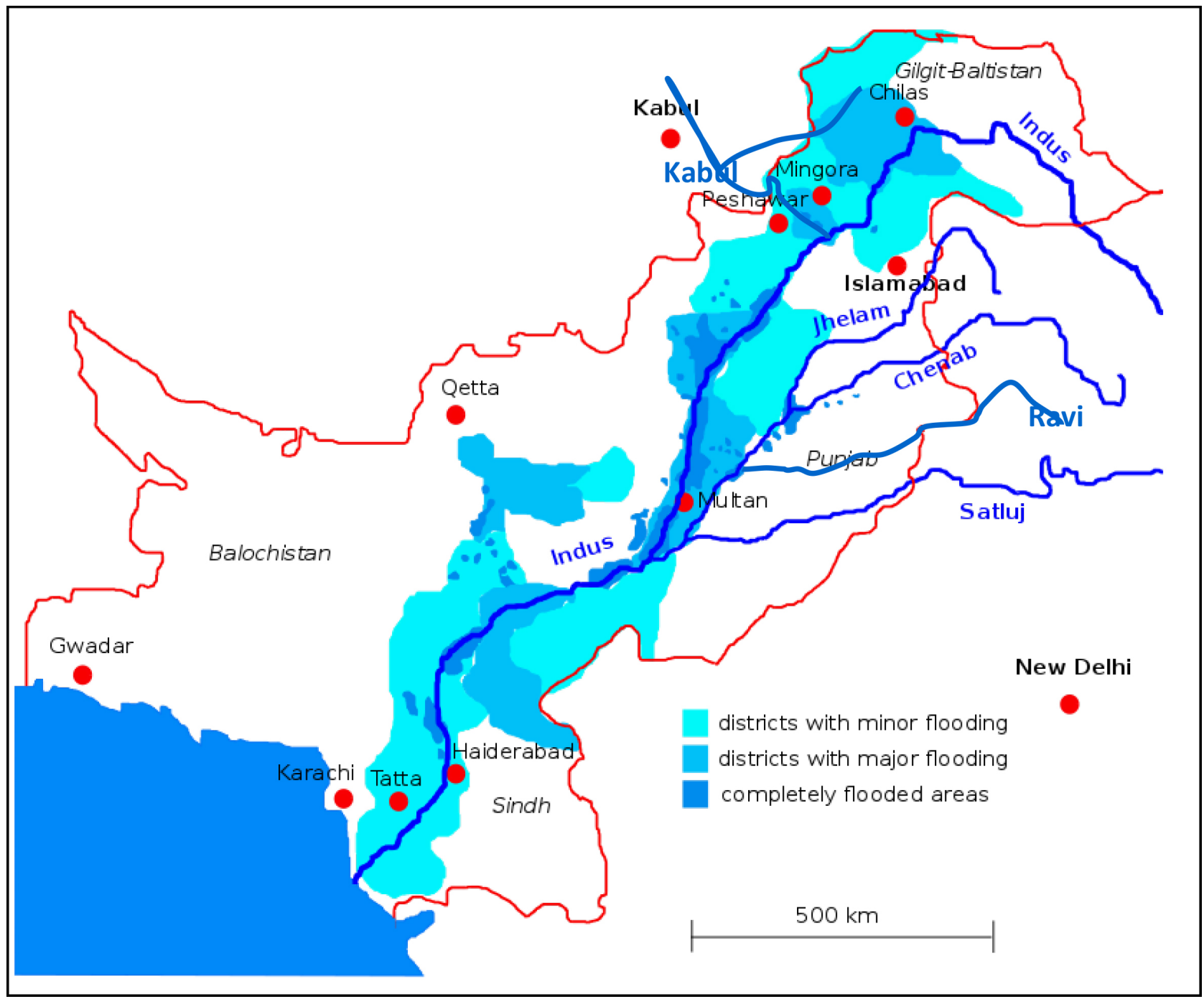

Figure 19. Flooded areas of 2010 floods as a result of monsoon rains concentrated in the catchment areas mainly of river Indus and Kabul in a single spell of 8-10 days.

\section{Storage Dams Requirements and World Bank Recommendations}

The water storage dams are multipurpose infrastructures extremely vital in $\mathrm{Pa}$ kistan especially in the present era of Global Climate Emergency for

1) Flow regulation as per need of irrigation from the seasonally available flow and floods of rivers or torrential flow Nulas. (ELCN)

2) Control of floods to avoid its disasters and calamities. (ELCN)

3) Cheapest hydropower generation if possible with available most suitable head and free of all heat, pollution, soot and greenhouse gasses generation. (EGLCN)

4) Storage and flow regulation over multi-years cycle duration as per need of Global Climate Calamities Controls through regular water cycle promotion and irrigation from the available flow and floods of river having decadal flow fluctuations. (EGLCN)

5) Global heat dissipation through regular water evaporation both directly 
through irrigation and indirectly through vegetation and plants (EGCN)

6) Global pollution, GHG and soot control through rains and agro-plants as a result of additional regulated flow for irrigation and thus water cycle promotions. (EGCN)

7) Freshwater aquaculture promotion. (ELCN)

The World Bank in its recommendations [13] had

1) Never ever considered the Global heat, temperature, Climate Disasters Control by water cycle promotion through storage dams and irrigation system.

2) No vision of avoiding huge pollution, GHG and soot through storage dams supported irrigation resulting in plants, vegetation, rains and snowfalls.

3) Never ever considered hydropower production by dams to avoid huge pollution, GHG, heat and soot addition in Global environment by its advised fossil fuel power plants.

4) Been continuously wasting hydropower potential of $86,000-93,000 \mathrm{MW}$ since 1980 avoiding daily addition of approximately more than $1.2384 \times 10^{16} \mathrm{~J}$ heat, 0.34 Million tons of pollution, 2.6 Million tons of $\mathrm{CO}_{2}$ and 0.07 Million tons of $\mathrm{SO}_{2}$ to the Global environments [22] if produced from fossil fuels.

5) Never ever considered the floods disaster control through storage dams. Thus no storage dam recommended to avoid huge flood disasters, faced almost every year. Flood disaster control is one of the prime and most vital needs for dam and WB has never ever given any minute weight-age to it.

6) Emphasized the 1000s of $\mathrm{Km}$. earthen embankment/bands/levees on the sides of river banks for blocking the flood water rushing out of its channel. The continuous disaster in livestock and agriculture sectors, rebuilding of thus damaged roads, bridges, buildings and other infrastructures, rescue and rehabilitation of flood affected peoples by the frequent breakage or overflow of these bands by floods, wastage of extremely precious water useable in agriculture and urban needs, abandoning the extremely cheap power production, aquaculture, re-recycling of this water in transport of global heat to troposphere over and above the Heavy amount persistently incurred in men (labor), materials and machinery in extensive construction, maintenance, repair, and vigilant supervision of these bands, in place of constructing storage dams and allied developments, are all cooking the penny worth tea on the fire by burning billions and trillions of currency notes of pounds and dollars.

7) Never ever considered to control the drainage of this extremely precocious water resource. About 1164 (1588 including absorbed and retained in flooded area) MAF drained to Arabian Sea in 34 years (Figure 2(a)) in the presence of its all recommended infrastructure and developments along with hundreds of trillions dollars loss.

8) Advised the system, which have never been able to even meet irrigation requirements inspite of huge floods in all 34 years (Figure 2(a)), wasting about 1588 MAF during this period and there is continuous contention between the provinces on irrigation water distribution being too small against the demand. One of the Chief Ministers of Pakistan has mourned on resulting outcomes of 
WB recommendations saying "we die by drowning when there are rains and die of thrust when there is no rain".

9) Never considered dam as multipurpose infrastructure with multiple benefits having too vital and vast utilities indicated above. It has rather thrashed it's all those vitalities one by one, all alone in individual aspects in place of considering multiple aspects altogether in a multipurpose infrastructure. Those thrashings too are on wrong, illogical, unscientific, baseless and complex reasoning and interpretations.

10) Extended the seasonal monsoon roaming to 5 months to reduce its storage estimate by subtracting future irrigational requirements of these five months from it. Absolutely wrong and illogical cuts are applied to the estimate. In the above analysis it is proved that $76 \%$ - $100 \%$ peak flood flow probability is in July and that too is only in 10 - 15 days with no requirement of any water for irrigation practically evident from Jhelum flow depression of July and August controlled for rains reduced demand (Figure 3, Figure 6(a), Figure 7). Also 23\% (average of 7 values, Figure 14, Figure 16 \& Figure 18) probabilities of pouring all monsoon rainfall loads in a single river's catchment area with extreme flow without any escape pocket and 35\% for two rivers are the driving parameters for the dam maximum possible capacity estimates. WB on the other hand mercilessly slaughtered them

a) By basing its estimates on average or mean flows. Reduced 150 to 115 MAF.

b) Neglecting the flow of 2 major rivers, Kabul and Chenab without any details of their water usage. Thus thrashed peak 60 and average 45 MAF.

c) Further by subtracting the absolutely illogical irrigation requirement of 5 months.

d) by increasing this cut with the developments in agriculture in place of reducing these cuts in view of rise in its demand.

e) and then applied a cut in the name of some yield.

f) and then further with some efficiency drive.

g) Then reducing the dam storage estimate by enlargement of canals with baseless view of canal extra storage. A fully running system cannot accept any additional supply during floods. Any such attempt will result in its complete collapse.

To reach the ultimate of 2 MAF for Jhelum and 15 MAF for Indus considering (just in a note without any detail) the full utility of flow of Kabul and Chenab rivers as per its report [13] pointed out at S/No. 11, in Table 6 below. This is the availability of flow for storage as per WB estimate and advised development has resulted in 1164 MAF drained to Arabian Sea and at least 424 MAF retained and absorbed (Figure 2(a)) in the flooded Area. The practical flow emphasizes it at least 190 MAF; rather 210 (S/No. 18, Table 6) with 10\% safety factor against 17 MAF. What a minute difference, only 173 rather 193 MAF, or 12 times of its estimate? The corresponding estimates on bases of different aspects by the author are shown for comparison in this Table 6 with matching background. 
Table 6. Indus river system flow statistics and its storage drives.

\begin{tabular}{|c|c|c|c|c|c|c|c|c|c|}
\hline \multirow{2}{*}{$\mathrm{S} / \mathrm{No}$} & \multirow[t]{2}{*}{ Flow in MAF $\downarrow$} & \multirow{2}{*}{\multicolumn{2}{|c|}{ Rivers $\rightarrow$}} & \multicolumn{2}{|c|}{ Indus+ Kabul Flows } & \multicolumn{2}{|c|}{ Jhelum+ Chenab Flows } & \multirow{2}{*}{$\begin{array}{c}\text { Grand } \\
\text { Total }\end{array}$} & \multirow{2}{*}{$\begin{array}{c}\text { Remar } \\
\text { ks }\end{array}$} \\
\hline & & & & \multicolumn{2}{|c|}{\begin{tabular}{|l|l|l|} 
Indus & Kabul & Total \\
\end{tabular}} & Jhelum Chenab & Total & & \\
\hline 1 & \multicolumn{3}{|c|}{ Maximum total flow } & \begin{tabular}{|l|l|}
72 & 38 \\
\end{tabular} & 110 & \begin{tabular}{|l|l|}
33 & 37 \\
\end{tabular} & 70 & 180 & \multirow{4}{*}{ 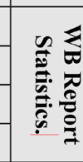 } \\
\hline 2 & \multicolumn{3}{|c|}{ Peak flow in peak-flow months } & 29 & 93 & 31 & 57 & 150 & \\
\hline 3 & \multicolumn{3}{|c|}{ Total average/mean flow } & 66 & 93 & 23 & 49 & 142 & \\
\hline 4 & \multicolumn{3}{|c|}{ Peak months average flow } & 22 & 79 & 16 & 36 & 115 & \\
\hline \multicolumn{10}{|c|}{ World Bank Estimates } \\
\hline 5 & \multicolumn{3}{|c|}{ Peak flow in peak-flow months } & \multicolumn{2}{|c|}{93} & \multicolumn{2}{|l|}{57} & 150 & \multirow[t]{2}{*}{-do- } \\
\hline 6 & \multicolumn{3}{|c|}{ Taken average flow in Peak months } & \multicolumn{2}{|l|}{79} & \multicolumn{2}{|l|}{36} & 115 & \\
\hline 7 & \multicolumn{3}{|c|}{$\begin{array}{l}\text { Neither } 150 \text { nor } 115 \text {, Storable flow after Chenab } \\
\& \text { Kabul flows } 42(60 \text { max.)MAF cuts }\end{array}$} & \multicolumn{2}{|l|}{54.2} & \multicolumn{2}{|l|}{15.7} & 69.9 & \multirow{3}{*}{ 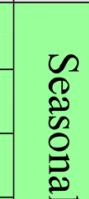 } \\
\hline 8 & \multicolumn{3}{|c|}{$\begin{array}{l}\text { Storable flow after } 85 \text {-irrigation cut along with so } \\
\text { called Feasible/economical cuts }\end{array}$} & \multicolumn{2}{|l|}{37.7} & \multicolumn{2}{|l|}{$11.8-3.3=8.5$} & 46.2 & \\
\hline 9 & \multicolumn{3}{|c|}{$\begin{array}{l}\text { Storable flow after } 2000 \text {-irrigation cut along with } \\
\text { Feasible/economical cuts }\end{array}$} & 22 & & 7.5 & & 29.5 & \\
\hline 10 & $\begin{array}{l}\text { Storable after efficien } \\
\text { with canals enlargem }\end{array}$ & $\begin{array}{l}\text { cy drive cut } \\
\text { ent infeasible }\end{array}$ & & 20 & & 6 & & 26 & \\
\hline $11 \mathrm{~s}$ & storable after canal re & modeling & & 15 & & 2 & & 17 & \\
\hline 12 & Agreed at final estim & ate* & & $15.5 / 19$ & & $6 / 7.5$ & & $21.5 / 26.5$ & \\
\hline 13 & Decadal storage esti & mate & & 26 & & 9 & & 35 & Decadal \\
\hline $14 \mid$ & $\begin{array}{l}\text { Final sites based (Tar } \\
\text { Sehven-manchar, Warsak }\end{array}$ & $\begin{array}{l}\text { (bela, Chasma, Chot } \\
\text {,Mangla) }\end{array}$ & tiari, & $\begin{array}{r}8.6+0.5+0.9+1 \\
12.8\end{array}$ & $8+1.0=$ & 8.77 & & 21.57 & $\overrightarrow{0}$ \\
\hline 15 & $\begin{array}{l}\text { Further site based }(\mathrm{Su} \\
\text { \& Low Gariala not } \mathrm{pc}\end{array}$ & $\begin{array}{l}\text { vat, Skardu, Kalabi } \\
\text { sssible) }\end{array}$ & oagh, & $\begin{array}{r}2+8.0=1 \\
6.0+4.0=10\end{array}$ & & 0 & & 20 & \\
\hline 16 & Total based on sites & & & 32.8 & & 8.77 & & 41.57 & \\
\hline & & & ut & 10r's Estin & & & & & \\
\hline Maxi & simum recorded flow & without cut to c & cope & e with monso & ons spa & atial roaming is & place of & f mean. & \\
\hline $17 \mathrm{~F}$ & Required Storage & To Arabian Sea & & & $3.7+21.5$ & $57=120.27$ & & 120 & \\
\hline 18 & $\begin{array}{l}\text { based on } 1973 \text { flood } \\
+ \text { existing storage } \\
\text { 21.5 MAF }\end{array}$ & $\begin{array}{c}\text { To Arabian Sea + } \\
\text { withheld in } \\
\text { flooded areas }\end{array}$ & $\begin{array}{r}98.7 \\
\text { Tot } \\
\text { Th }\end{array}$ & $\begin{array}{l}7+68.7+21.57 \\
\text { otal Silt load }=0 \\
\text { hus, it will ne }\end{array}$ & $\begin{array}{l}=188.9 \\
1811+0 . \\
\text { ed } 334\end{array}$ & $\begin{array}{l}7 \approx 190+10 \% \text { safet } \\
10332=0.284465 \mathrm{MA} \\
\text { years for silting to }\end{array}$ & $\begin{array}{l}\text { ty factor } \\
\mathrm{AF} / \text { year. } \\
50 \% \text {. }\end{array}$ & 210 & 要焉 \\
\hline 19 & $\begin{array}{l}\text { Storage for multi- } \\
\text { regulation with Add } \\
\text { MAF irrigation }\end{array}$ & $\begin{array}{l}\text { decadal flow } \\
\text { litional max. } 50 \\
\text { al releases. }\end{array}$ & & $\begin{array}{r}\text { At least } \\
\text { is will need } 4\end{array}$ & $\begin{array}{r}255+2 \\
87 \text { year } \\
\text { to } 5\end{array}$ & $\begin{array}{l}1.57=277 \mathrm{MAF} \text {. } \\
\text { rs for silting its c } \\
50 \% \text {. }\end{array}$ & apacity & 277 & है \\
\hline 20 & $\begin{array}{l}\text { Storage for multi- } \\
\text { regulation with Add } \\
\text { MAF irrigational r } \\
\text { of 34-37 year de }\end{array}$ & $\begin{array}{l}\text { decadal flow } \\
\text { litional max. } 40 \\
\text { eleases in view } \\
\text { cadal cycle. }\end{array}$ & & $\begin{array}{l}\text { At leasi } \\
\text { II need } 8\end{array}$ & $\begin{array}{l}475+2 \\
74 \text { year }\end{array}$ & $\begin{array}{l}21.5=497 \mathrm{MAF} \text {. } \\
\text { rs for silting its c } \\
50 \% \text {. }\end{array}$ & apacity & 497 & $\begin{array}{l}\frac{2}{3} \\
\frac{3}{2} \\
\frac{2}{2}\end{array}$ \\
\hline 21 & $\begin{array}{l}\text { Available Potential S } \\
\text { a. N-Warsak+ Mehn } \\
\text { b. Khaplu+Skardu+DMB-Dab } \\
\text { Tarap+Kalabagh+Chesl } \\
\text { c. Marala+Mangla+Rasul } \\
\text { Kunhar +Rohtas+Bunn } \\
\text { d. Jamrao+Sehwan-Mar }\end{array}$ & $\begin{array}{l}\text { torage Sits } \\
\text { nand +Ambahar } \\
+ \text { Tarbela+ } \\
\text { hma+Bunji } \\
+ \text { Aria. Nielum. Karot. } \\
\text { ah } \\
\text { nchar+ Chotiari }\end{array}$ & & $\begin{array}{l}\text { Available Stor } \\
25+2+7=3 \\
10+35+6+ \\
10+8.77+5 \\
115+1.8+0 \\
\text { his will need }\end{array}$ & $\begin{array}{l}\text { age Cap } \\
4 \\
4.6+152 \\
3.5+5+ \\
.9=117 \\
787 \text { ye }\end{array}$ & $\begin{array}{l}2+1.25+0.5+1=21 \\
5+3=85.27 \\
.7 \\
\text { ars for silting to }\end{array}$ & $\begin{array}{l}\text { Is Sits } \\
0.35\end{array}$ & 447.32 & 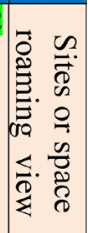 \\
\hline
\end{tabular}

Note: \$ unknown term with no details and no logic. Vol-1, pages 120-124; ${ }^{*}$ Table 5.5 page 123/Vol. 1 [13].

11) No recommendations for storage of precious flood water to avoid huge power and irrigational output loss. In place, it strongly emphasized the most costly (30 - 37 times $)$ both in initial investment and in running cost, the imported petroleum based power plants with baseless economical estimates in its support.

12) No consideration of storage at all on bases of spatial roaming of monsoons.

13) No consideration of storage on bases of over the year or decadal roaming 
of monsoons. It has pointed out in only a single sentence in each of 3 volumes of its report of about 400 pages each and in Vol. 2 closed this chapter altogether in the next sentence saying "IACA has not programmed for the long term aspects of the third stage providing over-year storage. For a region that is so dependent on water, the Indus Basin is not well suited geographically for the development of storage reservoirs. The topography of the country does not provide large reservoir sites which would be technically or economically easy to develop. Furthermore, the high silt content of the rivers, particularly of the Indus itself, would result in a fast rate of depletion of storage capacity." [13 vol. 2 page 89]. Tactfully discouraging without any solid proof and letting the hurdles grow in place of providing their solutions or at least warning the Government of Pakistan from any other development at potentials sites that may generate any further obstacle or problems in their future emerging vitalities of developments, it rather enforced them. This issue demands 497 MAF storages stated at S/No 20 in Table 6.

14) Site based storage is estimated to be $42 \mathrm{MAF}$, while the author has highlighted most vital sites (Figure 12) amounting to 447.32 MAF capacities stated in Table 6 with almost all multiple benefits and requirements and all urgently needed by all seven parameters of dam demands listed above.

15) Emphasized pumping of underground water in place of concentrating on

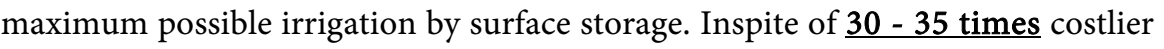
pumping with continuous consumption of costly imported petroleum generated power has been shown cheaper than almost free surface storage supply, by some ultramodern mathematics. This has damaged the aquifer level sustainability in many areas and crop-ability by slow poisoning by salinity.

16) Given too much emphasis on silt problems to discourage storage dams. On bases of its total silt load, the time for $50 \%$ storage capacity depletion is also indicated in Table 6, which shows that in the multi-decadal storage or monsoons spatial roaming based planning, it is not the problem of any minute worth before 335 - 875 years and by that time technical developments and new technologies will surely solve this problem in a most suitable way.

It is the time to review the forgone mistakes and blunders and avail the God Gifted opportunity in full in shape of 3 unique parts of Pakistan irrigation system stated below and explained as 3 regulation steps of GAC in [1].

\section{The 3 Unique Parts of Pakistan Irrigation System}

The irrigation system of Pakistan has 3 parts, each unique in the entire world, perhaps created particularly to handle the Global Environmental Emergencies with an opportunity of operative control in the hand of mankind, stated as the 3 regulation steps in GAC in [1].

1) The $1^{\text {st }}$ one is irrigation of eastern and southern Pakistan with 39 MAF water of its eastern 3 rivers, having 14.235 ZJ Global heat dissipation potential, presently blocked by WB sponsored IBWT. This move of WB has wide opened 
the gate for herds of all Global Climate Emergencies since 1970. This part is unique in the entire world by

a) Air wheel generation deserts on its east at the boarder of tropical zone.

b) Indian monsoon, the booster of the above stated air wheels.

c) Saudi Arabia and African Sahara desert, the huge and major Global heat source at high temperature readily available for heat dissipation on the route of those air wheels.

d) Easterlies, the carrier and speed booster of these air wheels.

e) Have opportunity to cycle $117 / 127$ times for its said goal.

These altogether form a unique group of facilitators, all with matching and compatible specifications and timings with no match in the entire world.

2) The $2^{\text {nd }}$ having $9.893 \mathrm{ZJ}$ Global heat dissipation potential is the irrigation of Northern Pakistan by its western 3 rivers, needing large storage dams, irrigation, drainage and power generation systems developments. This had mobilization opportunity in 1970s unfortunately again in hand of WB, but it tried to demolish it as pointed out in 16 aspects above in paragraph 4 and jeopardized it so badly that one cannot imagine. This part is unique in the entire world by the following facts.

a) Its monsoons feed is above 100 MAF.

b) It has largest and highest precipitation trap [1] on its north entrapped by 3 world's highest mountains ranges on its north and west and a world highest plane Deosai, with suitable patterns of ridges for easy and safe transmission of winds and clouds to it and valleys for easy and safe transport of precipitate, the water to its plane areas.

c) It has unique wind pattern on its east and south forcing and trapping the local evaporation to precipitate $70 \%-80 \%$ locally over and above the monsoon feed.

d) It has number of largest and highest glaciers to supply water to both the surface and underground concealed natural network.

e) Has one of the largest river systems in the world ready to play unique role in Global Emergency Control.

f) It has wide variety of rainy wind systems spread over the year to facilitate and promote its performance.

g) It has large gravity flow irrigated vast fertile planes for agriculture and water surface extension for WEPC of GAC to control GHT and its aftermaths.

h) It has four local anticlockwise whirling air cycles promoting and boosting evaporation, precipitation, rivers flows and local rains [4].

i) Its evaporated water through its irrigation has on the average a period of about 4 months to be $70 \%-80 \%$ available again for irrigation after evaporation and precipitation and traversing its path, both in air and on the land and thus re-recycling and regenerating about 150 MAF additional annual flows along with additional local moderate and frequent rains throughout the year. Thus in place of present overall about 130 MAF circulation in WEPC, 
it will rise to 393 MAF if all the available water is forced to irrigation through its storage dams regulated irrigation system in place of its drainage to Arabian Sea.

j) It has number of ideal potential dams' sites of about 400 - 447 MAF water storage capacity for decadal irrigation supply regulation.

k) It has at least 86,000 - 93,000 MW hydropower generations potential from its large flow with head about $3,300 \mathrm{M}$, all free from huge heat, pollution, soot and GHG as stated above in paragraph 4.

l) It benefits too much from the geographical and geophysical location of $\mathrm{Pa}$ kistan in the Earth Globe.

m) It has number of Natural Global Promoters of its rains like Indian both coastal summer winds supported by South Indian Topography from April to July feeding mainly to Northern Perception Trap [1] for river flow and partly dry relief for harvesting and next cultivation, African and Mediterranean promoted Naobahar wind in March, North polar winds and clouds traversing almost $2 / 3$ of the Globe in both longitude and latitude, initiated by Australia, carried over by Southern Westerly, then directed by western coastal mountains of American Continents, then redirected by Northern Westerly to Pakistan across the North Pole, through Russia and Afghanistan from December to February etc over and above the monsoons with July to September durations and relief of October to November for harvesting and next cultivation.

The high flow potential, its high head, large storable flow, large storage dams' capacity, large size gravity irrigate-able land, all mutually matching and compatible are for ideal and unique output. Thus, it has perhaps no match in the entire world.

3) The $3^{\text {rd }}$ having $15.78 \mathrm{ZJ}$ Global heat dissipation potential is the irrigation of Chulistan and Thar of Pakistan by 43 MAF water of its western 3 rivers, needing large storage dams and irrigation system developments of the $2^{\text {nd }}$ part stated above. This is unique in the entire world by all the parameters stated above for number one.

\section{Summary of the Findings}

From the above discussion it can be summarized that

1) IBWT implementation in 1960 has hurled ever increasing flood of calamities and disasters on the earth Globe since 1970 by blocking the functioning of major part of Natural Global Air Conditioner along with continuously and most critically overburdening the other two Earth Temperature Relievers, Oceans and Polar/glaciers ice. This is the most horrible event of twentieth century with its above aftermath flourishing continuously, undetected, which could be named as Silent Unspotted Crona-1960 (SUC-60) with global death tolls almost more than 60,000 a day since 1970.

2) For all Global Climate Calamities control and restoration of its pre 1960 
status, optimal mobilization of all parts of Water cycle of Pakistan is absolutely vital. The first immediate and most vital activity is the reversal of WB imposed IBWT, which rolled all the herds of present Global hazards and disasters in action since 1960 through blocking of $14.235 \mathrm{ZJ}$ global heat transport annually to troposphere. The $2^{\text {nd }}$ is the maximum possible storage and irrigation system development, all in parallel on all the storage sites, at least those indicated in Figure 12 along with that in Baluchistan and renovation with development of further needed irrigation, hydropower generation, drainage systems of rains and underground saline water, all in parallel as far as possible without any time lag. This could have relieved the above global heat load by 9.893 ZJ annually since 1980 , but having no vision of Global Climate Emergency (GCE) and its control based mainly and only in Pakistan water cycle, again the WB, the consultant for development of Water and Power Resources of Pakistan, not only missed this opportunity, even otherwise mishandled, rather absolutely misled and ruined Pakistan as pointed out above by 16 different crucial aspects and very serious issues. It pushed both local and Global interests too far in the pit that to recover it will cost much higher than that in 1980s. It let the extremely lethal heat constantly accumulated during last 50 years. The $3^{\text {rd }}$ is the development of irrigation system for Thar, Thal and Chulistan with $15.78 \mathrm{ZJ}$ global transport potential. All the 3 unique parts are needed to be mobilized vigilantly taking complete care of available resources particularly the roaming in time and space of its main feeder, the Indian monsoons to dissipate 50 years backlogs of global heat contents in about 52 years including 10 years mobilization periods [1].

3) The mobilization of all the 3 unique parts of Pakistan irrigation system is the only choice for control of GCE, and only opportunity for the human role. The mankind should recognize this natural blessing and immediately benefit from it comprehensively above all regional, political or religious motivations.

4) Indian monsoons, the main feeder of Indus River System has:

a) Space roaming with $29 \%$ probability of feeding almost only one river, $21 \%$ probability of feeding only two river, $12.6 \%$ of 3 rivers and only $4.5 \%$ in all the 4 rivers based on average of values stated in tables and graphs Figure 14, Figure 16 and Figure 18. The values of first two are quite stable and too much critical and dictate maximum possible storage on each river to grip all maximum flow in catchment area of that river. Figure 19 is an example of 2010 flood with almost all monsoon rains in catchment area of rivers Kabul, Indus and Jhelum and its 2000 cloud burst in Islamabad and Rawalpindi. Thus distribution of total storable water flow in number of rivers/dams and estimating the dam size on this basis is ridicules.

b) Seasonal roaming is mostly concentrating in July (June for Jhelum) and a bit less in August (Figure 10), mostly of one spell of 10 - 20 days extreme flooding in a year. During this period there may be local heavy rains much more than the safe limits for existing crops and it may be eminently needed to drain out extra rain water along with the irrigation supply in the pipelines too. Thus, worst case to 
handle, is the capability of maximum possible flow storage without any irrigation supply cut for these 10 - 20 days. In any case the irrigation utility cut in reservoir capacity must be avoided. This also dictates maximum possible storage to handle all the possible maximum flow on each river within a month without any cuts.

c) Over the years or decades, roaming main cycles are of 4, 18.6 and 37 years (sum of one 18.6 years high and next 18.6 of low flow) [8]. The 37 years cycle is most critical, which need critical planning and developments with intelligent and vigilant management. More than $255 \mathrm{MAF}$ additional storage (Figure 2(b)) is estimated with additional $50 \mathrm{MAF} /$ per year irrigation supply when considering only 18 year cycle. If 37 year cycle is made the bases of planning, which actually is the most required one in view of Global Climate Emergency and local irrigation demand, then it will be 475 MAF additional or total 500 MAF storage with $40 \mathrm{MAF}$ annual additional dispersal. Each river group should have of maximum possible storage size to hold in all the extreme flow of not a single, rather of 5 - 6 multiple years if possible, extremely needed for Global Temperature control, extremely vital for all the living animals including human beings and plants on the surface of the earth and below the surface of water in lakes, sea and Oceans too.

\section{Conclusions}

Following is concluded from the above.

1) Indian monsoons carry on roaming in space domain. The $23 \%$ probability of flood flow in only one and $35 \%$ for two rivers forces maximum possible storage on each river group for sake of continuous regulated flow release both for accumulated Global Heat dissipation and agriculture output.

2) Indian monsoons carry on roaming in season domain; mostly in one or two months, July and August (June-July for Jhelum) and rarely critical in others. In other word, these carry on roaming in 4 month time domain, but mostly in July and a bit less in August and much rarely in other months as shown for all the 4 rivers in Figure 10.

3) Indian monsoons carry on roaming in over the years' time or decadal domain. In this context, it has peak flow scattering in 4, 5, 8, 18.5 and 37 years cycles under responses of different mutual formats of mainly the lunar activities with solar, and Venus gravitational attraction variations and the solar seasons [8]. This dictates the planning of water storage and its release regulation based on 33 - 37 years cycle of Indus River System steered by Lunar Nodal Precession.

4) Storage estimated on bases of average flow is ridicules. The average flow is mostly only $75 \%$ of maximum and in the present scenario of Global heat and temperature, there is no way except to cash every possible remedial or soothing opportunity. Unless maximum flows are griped in storage dams, one can never be able to have a hold on its average.

5) As per practical observation, peak flood flow is generally for 10 - 15 days. Thus flood water storage in dams is mainly the game of $1-2$ weeks and never 
ever in 4 - 5 months. Hence, any reduction in dam storage capacity by their water usage in irrigation must absolutely be avoided. Conversely, the irrigated areas rather need drainage of water already in irrigation system along with rain water of local torrential rains more than the existing crops safe absorbability. The large storage capacity available in any dam has no binding on release of water at any time whenever needed and can stop when not required.

6) There is no logic in "Not considering storage to avoid flood flow disaster" as avoiding of flood disaster is one of the prime storage dams' demands. The cost of 60 - 70 years floods losses, the safety measures, management problems, panic, reconstruction of damaged infrastructures, rescue operations are comparable with dam construction cost, if not more than that. The difference is that finances incurred in levees is distributed over number of years and over number of heads mostly not accounted for and forcefully imposed mostly on the general public with ultimately no gain or regain, while dam cost is accumulated, distributed over only a few years with extremely huge gains over and above avoiding all losses and troubles stated above, both for at least more than a century.

7) GHT control, Irrigation, power demands and floods control are the main, rather vital reasons of storage dams.

8) Continuous rise of Global heat, temperature, hazards, calamities, wind and snow storms, hurricanes, floods etc. since 1970 is the aftermath of IBWT implementation since 1960 .

9) The IBWT implementation has crippled GAC and thus the heat is being continuously directed to the two safety valves, the Oceans and the polar and glaciers ice. These are accordingly, giving way to the load [1] monotonically and thus the ecosystem is critically on stack.

10) Storage dams for Irrigation and hydropower generation in Pakistan is almost only and lonely key for the control of Global Heat, Temperature and resulting Hazards and Calamities [1] over the entire Globe.

11) Storage and flow management at Mangla Dam has regulated Jhelum flow downstream. There are instances as that of 2002, 2010, 2014, 2016 and 2020 (Figure 1) with extremely heavy floods which demand further large storage on Jhelum.

12) The storage dams with extremely huge continuous financial gains are too much worth than $1000 s$ of miles of rocks, concrete and earthen embankment (bands) on the sides of the rivers to block the outflow of floods water from river channel, with too often huge multidimensional disasters by their breakage or overflow resulting into persistent draining of extremely huge amount of funds with ultimate no gain, but all drains away with too much troubles.

13) WB and its groups working on water storage, irrigation and power generation had no vision of GCE and their control linked with WEPC of Pakistan. Hence unknowingly extremely huge blunders have been committed in their estimates and recommendations. 
14) Also the WB and its groups have based their estimates on old and redundant paradigms and baseless perceptions if not biased or dictated by someone with vested interests.

15) WB has not considered the roaming of rain in only $1-2$ months and very rarely for 3, 4 or 5 and hence wrongly stretched it in $4-5$ months and then reduced the flow available for storage by the irrigation usage of 5 months. The monsoon rainfall carries on roaming in 1 - 2 month and mostly all in only one spell of 10 - 15 days. Thus reduction in storage in the name of irrigation usage of 4 - 5 months is ridicules, rather misuse of resources or wrong interpretations of information. Thus WB estimates on annual average peak flow with irrigation usage cuts is all ridicules.

16) Almost every year contention between the provinces and down between the end user on water distribution because of its acute scarcity in the wake of 1588 (annually 53) MAF going to waste is a wide open proof of WB design/recommendations absolute failure.

\section{Recommendations}

1) The cause of continuous rise of Global heat, temperature, hazards, calamities, wind and snow storms, hurricanes, floods etc since 1970 as the aftermath of IBWT implementation in 1960 must be thoroughly understood and its control strategy, the IBWT reversion must be given full considerations and immediate implementation.

2) All storage dams, flood diversion channels and additional irrigation and drainage systems indicated in Figure 12 must be constructed immediately for maximum possible water cycling.

3) Technology should take care and overcome all technical problems. Thus, there should be no evasion of any site on this ground.

4) The available head of flow more than $3500-200=3300 \mathrm{M}$ along the Indus must be fully utilized in hydropower production through all possible dams and power tunnels along with such for all rivers including a few indicated as yellow arrows in Figure 12.

5) The compatible and comprehensive irrigation and drainage systems must be developed simultaneously.

6) All the above stated developments must be carried out simultaneously in parallel or at least in logical order to catch and control the GHT promoted Calamities as early as possible by the UNO.

\section{Acknowledgements}

Author is highly thankful to all who helped, guided, reviewed and gave valuable suggestion in elaboration of all the points of this issue and to all the authors and publishers whose information/data/graphs has been used directly or indirectly, modified or reset or reformatted for this and previous papers for sake of human and Global safety and welfare. 


\section{Conflicts of Interest}

The author declares no conflicts of interest regarding the publication of this paper.

\section{References}

[1] Nazeer, M.M. (2020) New Insights in Prime Roles of Indian Subcontinent in Nurture of Global Heating and Hurricanes with Review of the Only Window for Their Calamities Control. Open Access Library Journal, 7: e6424. https://doi.org/10.4236/oalib.1106424

[2] Nazeer, M.M. (2019) Major Culprit behind Horrible Steep Rise of Global Heat Contents and Temperature since 1973 and It's Blockage Strategy. Vol. 10, IJSER Paper ID: 10132594.

[3] Nazeer, M.M. (2019) Mobilization of Water Cycle and Its Persian Air Wheel Heat Pump to Overcome Global Heating and Its Resulting Terrible Environmental Problems. Open Access Library Journal, 6, 1-17. https://doi.org/10.4236/oalib.1105445

[4] Nazeer, M.M. (2019) Reversal of Terrible Global Heating and Its Gang through Unique and Complete Water Evaporation and Precipitation Cycle of Pakistan. IJSER, 10, Paper ID: I0132180.

[5] No. 6032. India, Pakistan and International Bank for Reconstruction and Development. The Indus Waters Treaty 1960 (with Annexes). Signed at Karachi, on 19 September 1960. Protocol to the Above-Mentioned Treaty. Signed on 27 November, 2 and 23 December 1960. Official Text: English. Registered by India on 16 January 1962126 United Nations-Treaty Series 1962.

https://reaties.un.org/doc/Publication/UNTs/Volume\%20419/volume-419-I-6032English.pdf

[6] Azhar A. (2011) Indus Water Treaty, a Dispassionate Analysis. JSTOR Policy Perspectives, 8, 73-83. https://www.jstor.org/stable/42909289

[7] Shaheen, A. (2018) Indus Water Treaty: Challenges for Future. http://www.lead.org.pk/attachments/summerschool/day1/Indus\%20Waters\%20Tre aty\%20by\%20Dr\%20Shaheen\%20Akhtar.pdf

[8] Nazeer, M.M. (2020) Solar, Lunar and Venus Roles in Some Global Climatic Events. Open Access Library Journal, 7: e6419. https://doi.org/10.4236/oalib.1106419

[9] NASA and Dartmouth Observatory. https://floodobservatory.colorado.edu/SiteDisplays/294.htm https://floodobservatory.colorado.edu/GlobalFloodplains/070E040NCurrent.html https://floodobservatory.colorado.edu/GlobalFloodplains/070E040N.html

[10] 7 Escapage below Kotri Hydrological Year from April to March Source: WRMP WAPDA Based on Data Supplied by Govt. of Sindh. https://www.slideshare.net/zubeditufail/water-and-power-development-authoritymega-dam-projects-press-briefing-december-16-2005

[11] Ahmad, S. (2007) Land and Water Resources of Pakistan-A Critical Assessment. The Pakistan Development Review, 46, 911-937.

https://doi.org/10.30541/v46i4IIpp.911-937

https://www.pide.org.pk/pdf/PDR/2007/Volume4/911-937.pdf

[12] http://documents.worldbank.org/curated/en/251191548275645649/pdf/133964-WPPUBLIC-ADD-SERIES-22-1-2019-18-56-25-W.pdf 
[13] World Bank Report (1967) On Water and Power Resources of West Pakistan. Vol. 1:

http://documents.worldbank.org/curated/en/182331468758759382/pdf/multi0page.pdf http://documents.worldbank.org/curated/en/597841468098064172/pdf/multi0page.pdf Vol. 2:

http://documents.worldbank.org/curated/en/944011468091758375/pdf/multi0page.pdf Vol. 3:

http://documents1.worldbank.org/curated/en/336271468774973346/pdf/multi0page.pdf

[14] https://www.brighthubengineering.com/hydraulics-civil-engineering/52905-manni ng-equation-for-uniform-open-channel-flow-calculations

[15] Ali, A. (2013) Indus Basin Floods Mechanisms, Impacts, and Management. Asian Development Bank. http://www.dartmouth.edu/ floods/Archives/1988sum.htm

[16] Bhatt, C.M., Rao, G.S., Farooq, M., Manjusree, P., Shukla, A. and Sharma, S.V.S.P. (2017) Satellite-Based Assessment of the Catastrophic Jhelum Floods of September 2014, Jammu \& Kashmir, India. Journal of Geomatics, Natural Hazards and Risk, 8, 309-327. https://doi.org/10.1080/19475705.2016.1218943

[17] Ahmad, L., Parvaze, S., Majid, M. and Kanth, R.H. (2016) Analysis of Historical Rainfall Data for Drought Investigation Using Standard Precipitation Index (SPI) under Temperate Conditions of Srinagar Kashmir. Pakistan Journal of Meteorology, 13, 29-38.

https://www.researchgate.net/publication/319058599 Analysis of Historical Rainf all Data for Drought Investigation Using Standard Precipitation Index SPI Un der Temperate Conditions of Srinagar Kashmir

[18] Federal Floods Commission, Ministry of Water and Power, Government of Pakistan. http://mowr.gov.pk/wp-content/uploads/2018/06/Annual-Flood-Report-of-FFC-20 17.pdf

[19] Annual Flood Report 2018. Government of Pakistan Ministry of Water Resources. https://ffc.gov.pk/wp-content/uploads/2019/03/Annual-Flood-Report2018 2702201 9.pdf

[20] Major Flood Events Witnessed in Pakistan (2017) Federal Flood Commission, Ministry of Water Resources.

https://mowr.gov.pk/wp-content/uploads/2018/06/Annual-Flood-Report-of-FFC-2 017.pdf

[21] Aslam, M. (2018) Flood Management Current State, Challenges and Prospects in Pakistan: A Review. Mehran University Research Journal of Engineering and Technology, 37, 297-314. https://hal.archives-ouvertes.fr/hal-01744925/document https://doi.org/10.22581/muet1982.1802.06

[22] Nazeer, M.M. (2002) Growth Potential of Pakistan's Water Resources and Their Impact on Development. Science Vision Quarterly, a Journal of Science and Development, 8, 19-20. 
Abbreviations

\begin{tabular}{cccc}
\hline Abbreviations & Stands for & Abbreviations & Stands for \\
\hline GHC & Global Heat Contents & IBWT & Indus Basin water Treaty, 1960 \\
GHT & GHC \& Temperature & WEPC & $\begin{array}{c}\text { Water evaporation \& } \\
\text { precipitation cycle }\end{array}$ \\
GHG & Green House Gasses & & Millions Acre Foot volume \\
GAC & Global Air Conditioner & MAF & Zeta Joules = 10 $0^{21}$ Joules \\
WB & World Bank and its engaged & ZJ & groups \\
(ELCN) & Extreme Local concern & (EGCN) & Extreme Global concern \\
(EGLCN) & Extreme Global and local concern & GCE & Global Climates Emergencies \\
\hline
\end{tabular}

